\title{
Incorporating oral bioaccessibility into human health risk assessment due to potentially toxic elements in extractive waste and contaminated soils from an abandoned mine site
}

Neha Mehta ${ }^{1,2^{*}}$, Sabrina Cipullo ${ }^{3}$, Tatiana Cocerva ${ }^{4}$, Frederic Coulon $^{3}$, Giovanna Antonella Dino ${ }^{2}$, Franco Ajmone-Marsan ${ }^{5}$, Elio Padoan ${ }^{5}$, Siobhan Fiona Cox ${ }^{4}$, Mark R Cave ${ }^{6}$, Domenico Antonio De Luca $^{2}$

${ }^{1}$ Queen's University Belfast, School of Mechanical and Aerospace Engineering, Belfast, BT9 5AH, UK

${ }^{2}$ University of Torino, Department of Earth Sciences,Torino, 10125, Italy

${ }^{3}$ Cranfield University, School of Water, Energy and Environment, Cranfield, MK43 0AL, UK

${ }^{4}$ Queen's University Belfast, School of Natural and Built Environment, Belfast, BT9 5AG, UK

${ }^{5}$ University of Torino, Department of Agricultural, Forest and Food Sciences, Grugliasco, 10095, Italy

${ }^{6}$ British Geological Survey, Keyworth, Nottingham, NG12 5GG, UK

*Corresponding author: Neha Mehta (n.mehta@qub.ac.uk)

\section{Highlights}

$\mathrm{As}, \mathrm{Cd}, \mathrm{Pb}$ and $\mathrm{Zn}$ were present in high concentrations at abandoned mine (Gorno).

Oral bioaccessibility of potentially toxic elements was highly variable.

Calcareous geology, weathering and soil forming process influenced bioaccessibility.

Oral bioaccessibility inclusion avoids over-conservative human health risk assessment.

\begin{abstract}
The waste rock, tailings and soil around an abandoned mine site in Gorno (northwest Italy) contain elevated concentrations of potentially toxic elements (PTE) exceeding the permissible limits for residential uses. Specifically, the maximum concentrations of $\mathrm{As}, \mathrm{Cd}, \mathrm{Pb}$, and $\mathrm{Zn}$ were $107 \mathrm{mg} / \mathrm{kg}$, $340 \mathrm{mg} / \mathrm{kg}, 1064 \mathrm{mg} / \mathrm{kg}$ and $148433 \mathrm{mg} / \mathrm{kg}$, respectively. A site-specific human health risk assessment (HHRA) was conducted for residential and recreational exposure scenarios, using an approach based on Risk Based Corrective Action (RBCA) method, refined by incorporating oral bioaccessibility data.
\end{abstract}


Oral bioaccessibility analyses were performed by simulating the human digestion process in vitro (Unified BARGE Method). Detailed analysis of the oral bioaccessible fraction (BAF i.e. ratio of bioaccessible concentrations to total concentrations on $<250 \mu \mathrm{m}$ fraction) indicated BAF of As (5$33 \%), \mathrm{Cd}(72-98 \%), \mathrm{Co}(24-42 \%), \mathrm{Cr}(3-11 \%), \mathrm{Cu}(25-90 \%), \mathrm{Ni}(17-60 \%), \mathrm{Pb}(16-88 \%)$, and $\mathrm{Zn}$ (73-94\%). The solid phase distribution and mineralogical analyses showed that the variation of BAF is attributed to presence of alkaline calcareous rocks and association of PTE with a variety of minerals. The HHRA for ingestion pathway, suggested that bioaccessibility-corrected cancer risk reached up to $2.7 \times 10^{-5}$ and $0.55 \times 10^{-5}$ for residential and recreational senarios respectively (acceptable level is $1 \times 10^{-5}$ ). The hazard index $(\mathrm{HI})$ recalculated after incorporation of the oral bioaccessible concentrations for a residential scenario ranged from 0.02 to 17.9. This was above the acceptable level $(>1)$ for $50 \%$ samples, indicating potential health risks to local inhabitants. This study provides information for site-specific risk assessments and planning future research.

Keywords: Abandoned mine site; Bioaccessibility; Risk assessment; Solid phase distribution; Potentially toxic elements (PTE); Triassic western southern Alps (Italy)

\section{Introduction}

Mining contributes to the contamination of ecosystems by generating extractive waste (EW), also known as mining waste (Nakaona et al; 2019; Stewart, 2019). The EW from mineral extraction and processing has been accumulating for many years and the annual EW production is estimated to be of $350 \times 10^{9}$ tonnes per year (Vallero and Blight, 2019). Despite several measures have recently been implemented to manage EW in a more sustainable manner, release of PTE into the environment remains a concern, especially in areas with a legacy of historic mining. The Bureau de Recherches Géologiques et Miniéres (BRGM, French Geological Survey) estimates that there are more than 5200 million tonnes of waste rock and 1100 million tonnes of tailings stored in abandoned mines in the EU 
(BRGM, 2001). The high volume of EW in abandoned mines has led to human health concerns as these PTE tend to persist in the environment (Boente et al., 2020; Damian et al., 2018; De Souza et al., 2015; Delil and Koleli, 2019; Edokpayi et al., 2016; Karlsson et al., 2018; Kasemodel et al., 2019; Kaupilla et al., 2018; Khelifi et al., 2019; Petrella et al., 2019a; Petrella et al., 2019b; Väänänen et al., 2016; Wang et al., 2020; Yang et al., 2019).

A common approach used to assess the potential human health risks posed by contaminants is to conduct a human health risk assessment (HHRA). This entails determining the identity and extent of contaminants, characterising their toxicity and estimating the magnitude of their exposure to the local population (Adimalla, 2019; Gerba 2009; Zorpas 2020). Traditional HHRA methods use total concentrations of contaminants to assess potential risks. However, recent studies have emphasized that human health risks are associated with absorption of PTE into the systemic circulation (blood) (referred to as the bioavailable fraction) and indicated that consideration of total concentrations alone can result in overestimation of impacts on human health (Boim et al., 2019; Du et al., 2020; Fernández-Caliani et al., 2019; González-Grijalva et al., 2019; Ruby et al., 2002; Yu and Yang, 2019). Maddaloni et al. (1998) conducted oral bioavailability studies to measure the absorption of soilborne $\mathrm{Pb}$ into humans. Several other studies have applied in vivo animal studies and analysed oral bioavailable fractions (Bradham et al., 2016; Brattin and Casteel, 2013; Casteel et al., 2006; Juhasz et al., 2010; Kang et al., 2016; Suh et al., 2019). Nevertheless, assessing bioavailability requires complicated, lengthy and costly procedures that are also ethically constrained (Molina et al., 2013). This has resulted in the development of several in vitro bioaccessibility methods (Beauchemin et al., 2014) such as the Physiologically Based Extraction Test (PBET) by Ruby et al. (1996). The Unified BARGE method (UBM) was developed by the Bioaccessibility Research Group of Europe (BARGE), to harmonise oral bioaccessibility testing, which is now referenced as an ISO standard method (ISO 17924:2018). The oral bioaccessibility is this ISO method is defined as the fraction of a contaminant that is solubilised in the human gastrointestinal tract and is available for absorption (Wragg et al., 2011). The UBM method has been validated for in vivo studies for As, Cd, and Pb (Denys et al., 2009 
and 2012) and is widely applied by environmental consulting services in France and England (Foulkes et al., 2017; Pelfrêne et al., 2012). Recently, Mehta et al. (2019) examined the BAF of PTE in samples from an abandoned nickel (Ni) mine in Italy. Although, many studies have demonstrated the importance of oral bioaccessibility in assessing human health risks, there is a paucity of research on the incorporation of oral bioaccessibility into HHRA at abandoned mine sites.

Therefore, this study applies an oral bioaccessibility-correction for refining potential HHR in an abandoned mine located in Gorno, northwest Italy. Specifically, the objectives were to: (1) determine the PTE bioaccessible fractions in waste rock, tailings and contaminated soils; (2) investigate the effects of mineralogy and solid phase distribution on the bioaccessible PTE fractions; and (3) perform bioaccessibility-corrected HHRA to calculate risks to human health via the oral pathway.

\section{Methodology}

\subsection{Study site and sampling}

The abandoned mine site is located in the Gorno mining district comprising of the Seriana, Riso, and Brembana valleys (Lombardy, northwest Italy). The site is composed of Triassic carbonate rocks of the central southern Alps (Fig.1) that were formed due to crustal movements and volcanic activities (Hou et al., 2016; Leach et al., 2010). The study site for this investigation is a waste facility located in the vicinity of Mount Arera, one of the biggest and most accessible facilities in the region (Dino et al., 2018).

The site is rich in zinc-lead-silver stratabound ore deposits with mineralisation of $\mathrm{Zn}-\mathrm{Pb} \pm \mathrm{Ag} \pm$ baryte \pm fluorite mostly occurring within the "Metallifero" (i.e., "ore-bearing") formation, (also known as the Gorno formation - (Dino et al., 2018). The primary mineralisation consists of sphalerite ( $\mathrm{ZnS}$ ) and galena $(\mathrm{PbS})($ average $\mathrm{Zn} / \mathrm{Pb}$ ratio= $5: 1)$, with minor pyrite $\left(\mathrm{FeS}_{2}\right)$, marcasite $(\mathrm{FeS} 2)$, chalcopyrite $\left(\mathrm{CuFeS}_{2}\right)$ and argentite $\left(\mathrm{Ag}_{2} \mathrm{~S}\right)$. The dominant gangue minerals are calcite $\left(\mathrm{CaCO}_{3}\right)$, dolomite $\left(\mathrm{CaMg}\left(\mathrm{CO}_{3}\right)_{2}\right)$, quartz $\left(\mathrm{SiO}_{2}\right)$ and ankerite $\left(\mathrm{Ca}(\mathrm{Fe}, \mathrm{Mg}, \mathrm{Mn})\left(\mathrm{CO}_{3}\right)_{2}\right)$. The industrial exploitation for $\mathrm{Zn}$ and $\mathrm{Pb}$ took place between 1837 and 1982. A flotation process, using sodium based reagents and fuel 
oil, was applied for the treatment of valuable ores (information from historical documents maintained by the Municipal Corporation of Gorno). Hence, the two main types of EW present at the site are waste rock and tailings due to the separation and treatment processes. Samples of waste rock $(n=10)$, tailings ( $\mathrm{n}=10)$ and soil $(\mathrm{n}=3)$ were collected (sampling procedure in Supplementary Material: S1).

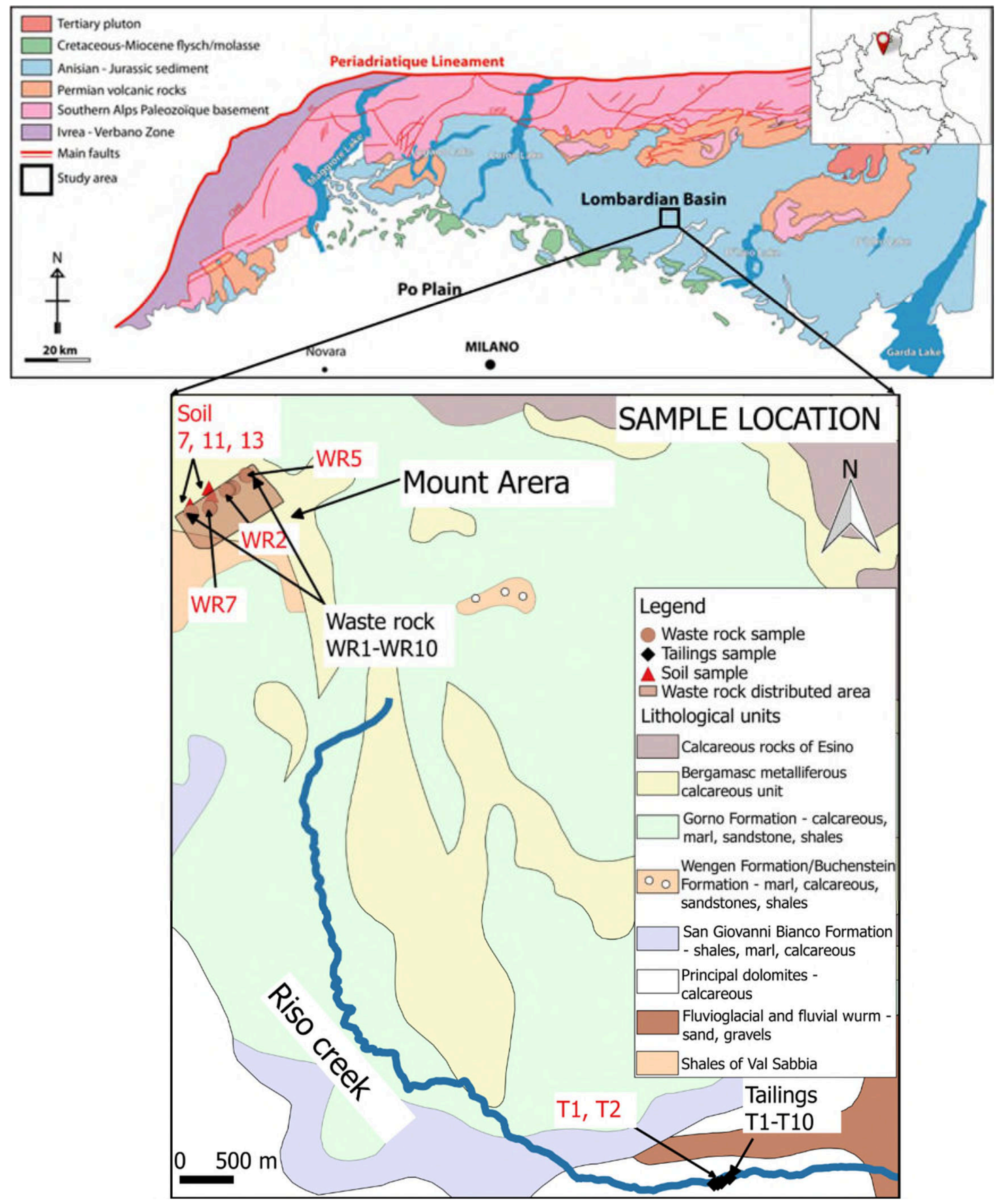

Fig.1. Geological setting with insert showing geographical location (modified from Beltrando et al., 2015) and the sample locations at Gorno. Sample numbers are shown in red font for samples analysed for bioaccessibility. WR: waste rock, T: tailings, and S: soil 


\subsection{Analytical methods}

\subsubsection{Basic physical-chemical characteristics}

The waste rock, tailings and soil samples were dried in an oven at $80{ }^{\circ} \mathrm{C}$ until the weight remained constant. All samples were sieved to $<2 \mathrm{~mm}$ and quartered to obtain a representative sample size of $10 \mathrm{~g}$. The mineralogical analysis of waste rock, by Dino et al. (2018) showed presence of calcite, dolomite, and sphalerite. Tailings contained calcite, dolomite, $\mathrm{Fe}$ sulphates and $\mathrm{Pb}$ sulphosalts. The soil samples were studied for mineral phases using micro-X-ray fluorescence (micro-XRF) Eagle IIIXPL spectrometer equipped with an EDS Si (Li) detector and with an EdaxVision32 microanalytical system. Detailed micromorphology was conducted using a Cambridge Stereoscan 360 scanning electron microscope (SEM) coupled with energy-dispersive spectrometry on soil sample (Code - S7). All samples were analysed for $\mathrm{pH}$ using a 1:2.5 suspension of sample in water (ISO 10390:2005). The total concentrations of PTE in $<2 \mathrm{~mm}$ fraction were determined using aqua regia (U.S. EPA 3051A and U.S. EPA 6010C, 2007). Briefly, $0.5 \mathrm{~g}$ of sample was digested using concentrated $\mathrm{HNO}_{3}$ and $\mathrm{HCl}\left(1 \mathrm{HNO}_{3}: 3 \mathrm{HCl}\right)$. The concentrations of extracted PTE were measured using an Ametek Spectro Genesis Inductively Coupled Plasma-Optical Emission Spectrometer (ICP-OES) provided with an Ametek monochromator, a cyclonic spray chamber and a TeflonMira Mist nebulizer. All reagents used were of analytical grade. High-purity water from a Millipore Milli-Q Academic system was used. All samples were analysed in duplicate.

\subsubsection{Oral bioaccessible concentrations}

Following the basic physical-chemical-mineralogical characterisation, samples were selected for bioaccessibility analyses. Waste rock and soil samples were selected to ensure a representation of each dump and lithology from the Gorno site, so that results can be representative of the area. For tailings, the two shallowest samples were selected. The samples were sieved to $<250 \mu \mathrm{m}$ fraction and analysed for total and bioaccessible concentrations using aqua regia extractions and UBM, respectively (BARGE 2010; Denys et al., 2012; ISO 17924:2018). For quality control, each batch of UBM extractions $(n=10)$ included one procedural blank, six unknowns, one duplicate of two 
unknown samples and one soil guidance material (BGS102) (BARGE, 2010; Hamilton et al., 2015). Table in (Supplementary Material: S2) summarises the measured and certified values of the BGS102 extractions. The extractions consisted of two phases: gastric and gastrointestinal. Bioaccessible concentration was considered as the highest concentration from gastric or gastrointestinal phase, as this allowed HHRA estimations to be a "worst-case" scenario. Bioaccessible fraction is reported as the ratio of bioaccessible concentration compared with the total concentration from the $250 \mu \mathrm{m}$ fraction (Eq. 1).

$B A F(\%)=\frac{\text { Bioaccessible concentration of element }\left(\frac{\mathrm{mg}}{\mathrm{kg}}\right)}{\text { Total concentration of element }\left(\frac{\mathrm{mg}}{\mathrm{kg}}\right)} \times 100$

\subsubsection{Non-selective sequential extractions}

Potentially toxic elements occur in soil in association with a complex mixture of chemical components, e.g. mineral phases; pore-water; and organic matter. Consequently, the occurrence and relative distribution of PTE among these components control PTE dissolution and hence bioaccessibility (Ettler et al., 2018; Ettler et al., 2019; Vasiluk et al., 2019). Solid phase distribution in this study was performed by a non-selective method coupled to the chemometric identification of substrates and element distributions (CISED) method (Cave et al. 2004; Cipullo et al., 2018). The CISED method prevents resorption of elements to soil during extraction process due to the short time the extractant is in contact with samples. Moreover, it provides necessary information on the presence of PTE within various matrices. The mechanistic information about PTE solid phase associations can help in understanding leachability, solubility and mobility of PTE, elucidating the effects of mineralogical forms for in vitro bioaccessibility (CIEH, 1999; Cox et al., 2013; Palumbo-Roe and Klinck, 2007; Schaider et al., 2007).

The CISED extractions were carried out on selected samples ( $\mathrm{n}=2$ each for waste rock, tailings, and soil) to determine the distribution of elements. Approximately $2 \mathrm{~g}$ of sample was sequentially 
extracted with $10 \mathrm{ml}$ of extractant. The solution was mixed for $10 \mathrm{~min}$ in an end-over-end shaker, centrifuged (4350 $\mathrm{g}$ for $5 \mathrm{~min}$ ) and the resultant leachate (liquid fraction) was collected in a clean sample bottle. The next extraction solution was added to the same sample and the process repeated. Seven different solutions were used twice (deionised water, $0.01 \mathrm{M}, 0.05 \mathrm{M}, 0.1 \mathrm{M}, 0.5 \mathrm{M}, 1.0 \mathrm{M}$ and 5.0 $\left.\mathrm{M} \mathrm{HNO}_{3}\right)$, with progressive addition of $\mathrm{H}_{2} \mathrm{O}_{2}(0.25,0.50,0.75$ and $1 \mathrm{ml})$ in the last four solutions for precipitation of oxides. The recovered liquid fraction was filtered with a $0.45 \mu \mathrm{m} 25 \mathrm{~mm}$ nylon syringe filter and diluted four times with deionised water for elemental analysis using ICP-MS (NexION® 350D ICP-MS, Perkin Elmer). For quality control, acid blanks (1\% nitric acid) and guidance material (BGS102) were included in extraction. The solid phase distribution of major and trace elements was determined using a self-modelling mixture resolution algorithm (SMMR) developed by Cave et al. (2004) in MatLab®Version R2015. The detailed analytical methods can be found in Mehta et al. (2019).

\subsection{Human health risk assessment for ingestion}

The Risk Based Corrective Action (RBCA) guidelines (ASTM 1995; ASTM 2015); and the exposure frequencies from the U.S. EPA (2002) and the APAT-ISPRA, 2008 (Italian databases to conduct risk assessment) were used to conduct HHRA for two scenarios: (1) a worst case scenario for residential area (i.e. taking exposure frequency (EF) as 350 days a year for 24 hours a day (U.S. EPA 1991), and (2) a more realistic recreation scenario, with site-specific human activity patterns assumed, for which the number of outdoor weeks were limited to 32 weeks a year (mid March to mid November) and 3 hours a day of outdoor time (APAT-ISPRA, 2008; Bharadwaj and Machibroda, 2008). The numerical estimation of risks due to ingestion of non-carcinogenic PTE was evaluated as hazard quotient (HQ) and for carcinogens as cancer risk (CR) (Eq. 4 and 5). The total PTE concentrations on $<250 \mu \mathrm{m}$ size fraction were used as the concentration at source $\left(\mathrm{C}_{\mathrm{s}}\right)$. It should be noted that the Italian regulation suggests to use total concentration on $<2 \mathrm{~mm}$ fraction normalised to weight of $<20 \mathrm{~mm}$ fraction. 
However, as the oral bioaccessibility analysis using UBM was performed on $<250 \mu \mathrm{m}$ samples in this study, both the BAF and the risk calculations were determined for $<250 \mu \mathrm{m}$ fraction, without normalisation for consistency. This is further supported by the U.S. EPA (2007 and 2008), approach which reported that the $<250 \mu \mathrm{m}$ fraction is the main fraction that adheres to human skin and results in incidental ingestion. Average daily dose (ADD) was calculated by considering the receptor to be both children and adults, body weight (BW) $70 \mathrm{~kg}$ for adult and $15 \mathrm{~kg}$ for children from U.S. EPA,

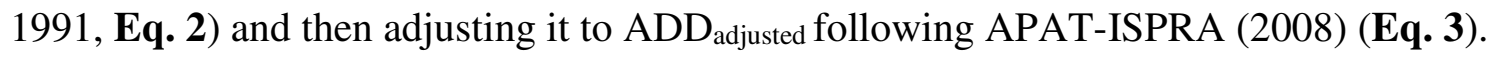

$$
\begin{gathered}
A D D=C_{s} \times\left(\frac{I R \times E F \times E D \times 10^{-6}}{B W \times A T}\right) \\
A D D_{\text {adjusted }}=\left\{\begin{array}{lr}
A D D_{\text {children }}+A D D_{\text {adults }} & \text { for carcinogens } \\
A D D_{\text {adults }} & \text { for noncarcinogens }
\end{array}\right.
\end{gathered}
$$

where, IR is ingestion rate (adults: $100 \mathrm{mg}$ /day and children: $200 \mathrm{mg} / \mathrm{day}$ - (U.S. EPA, 2002)), ED is exposure duration (children: 6 years; adults: 24 years - (U.S. EPA, 1991)), AT is averaging time (for non-carcinogens: $\mathrm{ED}$, carcinogens: 70 years) and $10^{-6}$ is for unit conversion,

$$
\begin{aligned}
& H Q=\frac{A D D_{\text {adjusted }}}{R f D} \\
& C R=A D D_{\text {adjusted }} \times C S F
\end{aligned}
$$

Reference dose (RfD) is 0.0003, 0.0005, 0.0003, 1.5, 0.04, 0.02, 0.0035 and 0.3 mg/kg-d for As, Cd, $\mathrm{Co}, \mathrm{Cr}, \mathrm{Cu}, \mathrm{Ni}, \mathrm{Pb}$ and $\mathrm{Zn}$, respectively. Cancer slope factors (CSF) are $\mathrm{As}$ and $\mathrm{Pb}$ are 1.5 and 0.0085 $(\mathrm{mg} / \mathrm{kg}-\mathrm{d})^{-1}$ (U.S. EPA IRIS, 2019). These CSF and RfD values are also in accordance with Ministero dell'ambiente e della tutela del territorio e del mare, 2006, decree no. 152/06 (The Ministry for Environment, Land and Sea Protection of Italy, 2006).

As exposure to two or more contaminants may result in accumulative effects, HQ can be summed as hazard index (HI) (Eq. 6). A, HI <1 represents no significant risk of non-carcinogenic effects, whereas $\mathrm{HI}>1$ represents a chance of non-carcinogenic effects, with an increase in probability as HI 
increases (U.S. EPA, 2011). Cancer risk (CR) of $\mathrm{CR}<1 \times 10^{-6}$ and $\mathrm{CR}_{\text {total }}<1 \times 10^{-5}$ is generally regarded as acceptable, where $\mathrm{CR}_{\text {total }}$ is the summation of cancer risks of individual contaminants as expressed in Eq. 7.

For incorporating oral bioavailability in $\operatorname{HHRA}\left(\mathbf{E q . ~ 8 , 9 ) , ~} \mathrm{ADD}_{\text {adjusted }}\right.$ must be multiplied by relative bioavailability (RBA) (i.e. the ratio of absolute bioavailability of the test material ( $A B A_{\text {test }}$ ) to the absolute bioavailability of the reference dose material (ABA $\left.\mathrm{A}_{\text {reference}}\right)$ (Vasiluk et al., 2011). However, as bioaccessibility $\geq$ bioavailability, BAF can be used as conservative proxy to replace $\mathrm{ABA}_{\text {test }}$. In

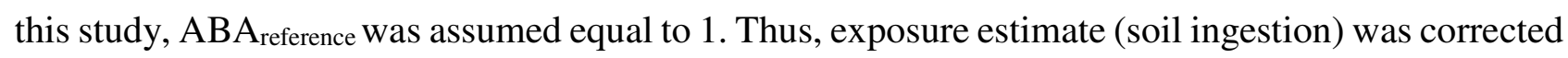
when estimating HQ and CR (Eq. 10). A similar methodology was applied by Luo et al. (2012) and Cao et al. (2020) for incorporating oral bioaccessibility in HHRA due to PTE contamination in urban parks of China and e-waste burning site in Accra, Ghana, respectively.

$$
\begin{aligned}
& H I=\sum_{m=1}^{i} H Q_{m} \\
& C R_{\text {total }}=\sum_{m=1}^{i} C R_{m} \\
& A D D_{\text {adjusted bio }}=A D D_{\text {adjusted }} \times R B A \\
& A D D_{\text {adjusted bio }}=A D D_{\text {adjusted }} \times\left(\frac{A B A_{\text {test }}}{A B A_{\text {reference }}}\right) \\
& A D D_{\text {adjusted bio }}=A D D_{\text {adjusted }} \times\left(\frac{B A F \text { in } \%}{100}\right)
\end{aligned}
$$

\section{Results and discussion}

\subsection{Mineralogical analysis}

Semi quantitative analysis using micro-XRF demonstrated presence of calcite, dolomite, zinc oxide, and sphalerite as abundant minerals in soil. The minor minerals were galena, lead oxide, pyrite, and 
smithsonite. The results from SEM analysis on soil (sample code - S7) (Fig.2) showed that As was associated with Fe rich grains, suggesting strong presence of As in Fe rich phases asthe adsorption of As species occurs by ligand exchange of $\mathrm{As}$ for $\mathrm{OH}_{2}$ and $\mathrm{OH}$ groups on $\mathrm{Fe}$ oxide hydroxide surfaces (Filippi et al., 2015; Jain et al., 1999). Arsenic was present within grains rich in Ca and Mg (dolomite rich), which can be explained by surface precipitation of small amounts of poorly ordered $\mathrm{Fe}$ (hydr)oxides with high specific surface area and adsorption capacity to dolomite rich minerals. Arsenic was also present in grains rich in clay minerals (indicated by presence of As-K-Mg silicates). Copper mainly occurred as chalcopyrite $\left(\mathrm{CuFeS}_{2}\right)$. Careful visual examination of the $\mathrm{Cd}$ map shows that $\mathrm{Cd}$ was also associated with chalcopyrite. Chalcopyrite tends to host trace elements such as $\mathrm{Cd}$ in sulphide ore deposits (Clark et al., 2001). Lead was present as galena, $\mathrm{PbO}, \mathrm{PbCO}_{3}$ and amorphous sulphides. Zinc was observed as zinc oxide, $\mathrm{Cu}-\mathrm{Fe}-\mathrm{Zn}-\mathrm{S}$ phase, hemimorphite, sphalerite, smithsonite, and with clay minerals (Zn-K-Mg-Si). 


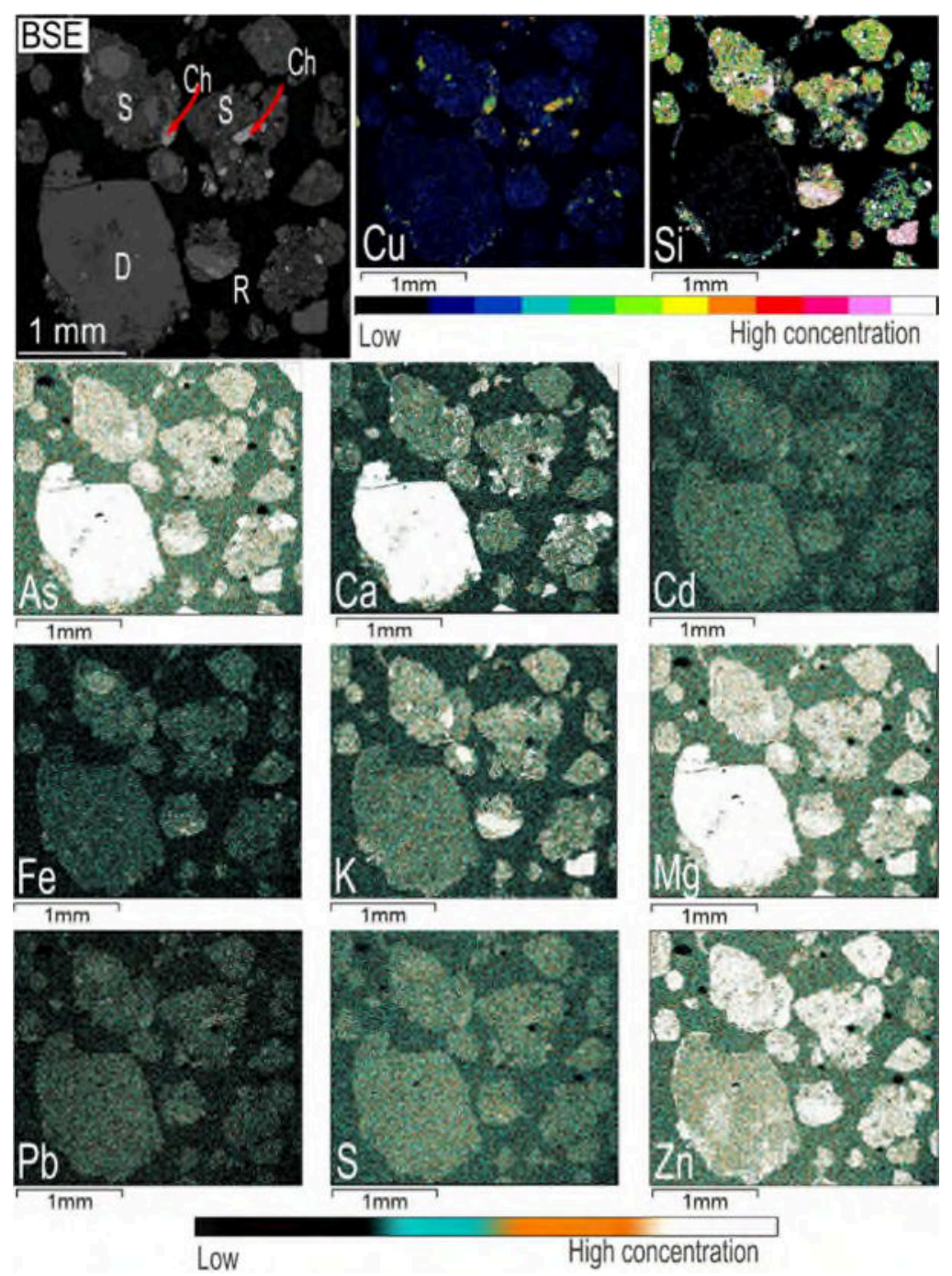

Fig.2. Elemental distribution and composition of soil (sample code -S7) - Back scattered electron (BSE) micrograph showing Ch: chalcopyrite, D: dolomite, R: resin, S: sphalerite and zinc oxide and corresponding X-ray maps (SEM) for $\mathrm{Cu}, \mathrm{Si}, \mathrm{As}, \mathrm{Ca}, \mathrm{Cd}, \mathrm{Fe}, \mathrm{K}, \mathrm{Mg}, \mathrm{Pb}, \mathrm{S}$, and $\mathrm{Zn}$.

\subsection{Total concentrations of PTE in the $2 \mathrm{~mm}$ fraction of the waste rock, tailings and soil}

The $\mathrm{pH}$ of waste rock samples varied between 7.4 and 7.9 (Fig.3). Zinc was present in high levels compared to Italian legislative limits with an average concentration of $73900 \mathrm{mg} / \mathrm{kg}$. This occurred due to early mining operations at Gorno where $\mathrm{Zn}$ was extracted from zinc oxide and zinc silicates and not from sphalerite (Dino et al., 2018), contributing to waste rock dumps with high concentrations of $\mathrm{Zn}$ from sphalerite $(\mathrm{ZnS})$. The weathering of these waste rocks results in enrichment of the $<2 \mathrm{~mm}$ fraction with secondary minerals of ZnS. Strong Cd enrichment (range $52-340 \mathrm{mg} / \mathrm{kg}$ ) was observed due to the chemical similarity with Zn (Das et al., 1997). Strong geochemical associations between 
both elements have been found also in other mining sites e.g. lead-zinc mines in Upper Silesia (Poland) and Zawar (India) (Anju and Banerjee, 2011; Ullrich et al., 1999).

The concentrations of thallium ( $\mathrm{Tl}$ ) were found to be $>1 \mathrm{mg} / \mathrm{kg}$ (limit for green and residential areas) as $\mathrm{Tl}$ is an accompanying element to $\mathrm{Pb}-\mathrm{Zn}$ ores and can be introduced to the environment due to processing of these ores (Lis et al., 2003). Total As concentrations ranged from 13 to $68 \mathrm{mg} / \mathrm{kg}$, with mean concentration of $45 \mathrm{mg} / \mathrm{kg}$. The possible reason could be that pyrite $\left(\mathrm{FeS}_{2}\right)$, galena $(\mathrm{PbS})$, sphalerite $(\mathrm{ZnS})$, marcasite $\left(\mathrm{FeS}_{2}\right)$ and chalcopyrite $\left(\mathrm{CuFeS}_{2}\right)$ are commonly known to contain As as an impurity (Yan-Chu, 1994). The average concentration of antimony (Sb) was $30 \mathrm{mg} / \mathrm{kg}$. This can be attributed to the fact that As and Sb share chemical featuresresulting in similar behaviour (Wilson et al., 2010). Copper $(\mathrm{Cu})$ was found to vary from $30 \mathrm{mg} / \mathrm{kg}$ to $184 \mathrm{mg} / \mathrm{kg}$, with an average concentration of $88 \mathrm{mg} / \mathrm{kg}$. The samples showed trace concentrations of the ferromagnesian elements i.e. Cr-Ni-V-Co, and Se due to carbonatic platform (Bullock et al., 2019; McLennan, 2001).
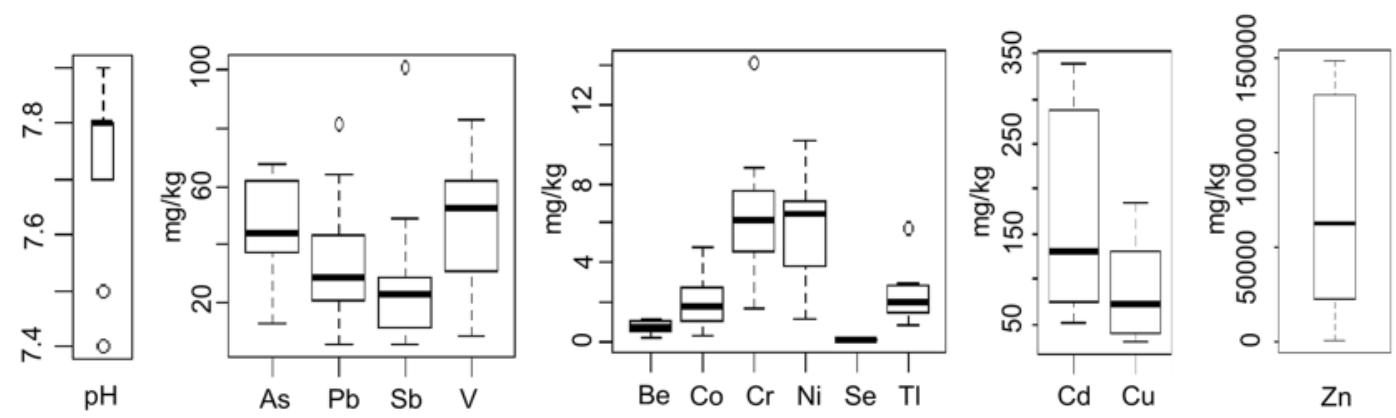

Fig.3. $\mathrm{pH}$ and concentration of PTE in $\mathrm{mg} / \mathrm{kg}$ in waste rock samples (fraction $<2 \mathrm{~mm}$ ).

Tailings and soil samples had alkaline $\mathrm{pH}$ values (Table 1). Tailings collected from $0-15 \mathrm{~cm}$ depth, had considerably less PTE compared to samples taken at increasing depths. The plausible reasons are: (1) top layer is essentially a soil layer while all other samples were tailings. These tailings were deposited in the area during processing of valuable ores; (2) leaching of PTE during rainfall events can result in greater contamination with increasing depth.

Tailings showed higher concentrations of $\mathrm{As}, \mathrm{Cd}, \mathrm{Cu}, \mathrm{Pb}, \mathrm{Sb}$ and $\mathrm{Zn}$ compared to the permissible limits in Italy. The Cd concentration was as low as $0.1 \mathrm{mg} / \mathrm{kg}$ at the surface but reached to $24.2 \mathrm{mg} / \mathrm{kg}$ 
at $125-175 \mathrm{~cm}$ depth. The concentration of $\mathrm{Zn}$ was $52 \mathrm{mg} / \mathrm{kg}$ at the sampling point close the surface and reaching $8887 \mathrm{mg} / \mathrm{kg}$ at $200 \mathrm{~cm}$ depth. The total $\mathrm{As}, \mathrm{Sb}$ and Cd concentrations in tailings ranged from 74 to $107 \mathrm{mg} / \mathrm{kg}, 17$ to $319 \mathrm{mg} / \mathrm{kg}$, and 14 to $88 \mathrm{mg} / \mathrm{kg}$, respectively. Soil samples were also found to be contaminated by $\mathrm{As}, \mathrm{Cd}, \mathrm{Pb}, \mathrm{Sb}, \mathrm{Tl}, \mathrm{V}$, and $\mathrm{Zn}$, which can result in environmental problems and cause damage to human health due to ingestion. 
Table 1. pH and concentration of PTE in soil and tailings samples from Gorno in size fraction <2 mm.

\begin{tabular}{|c|c|c|c|c|c|c|c|c|c|c|c|c|c|c|c|}
\hline & Sample & $\begin{array}{l}\text { Depth } \\
\text { (cm) }\end{array}$ & $\mathrm{pH}$ & As & $\mathbf{B e}$ & $\mathbf{C d}$ & Co & $\mathrm{Cr}$ & $\mathbf{C u}$ & $\mathbf{N i}$ & $\mathbf{P b}$ & $\mathrm{Sb}$ & $\mathbf{T l}$ & $\mathbf{V}$ & $\mathbf{Z n}$ \\
\hline Limit 1 & & & & 20 & 2 & 2 & 20 & 150 & 120 & 120 & 100 & 10 & 1 & 90 & 150 \\
\hline Limit 2 & & & & 50 & 10 & 15 & 250 & 800 & 600 & 500 & 1000 & 30 & 10 & 250 & 1500 \\
\hline \multicolumn{16}{|c|}{ Tailings sampling point 1} \\
\hline & $\mathrm{T} 1$ & $0-15$ & 6.9 & 8.0 & 0.4 & 0.1 & 2.6 & 5.9 & 9 & 8.7 & 879 & 1 & 0.07 & 41.4 & 52 \\
\hline & $\mathrm{T} 2$ & $15-50$ & 7.2 & 42.2 & 0.4 & 20.3 & 2.3 & 4.2 & 246 & 3.7 & 1005 & 116 & 0.07 & 30.1 & 7554 \\
\hline & $\mathrm{T} 3$ & $125-175$ & 7.5 & 45.3 & 0.4 & 24.2 & 1.4 & 3.5 & 219 & 1.7 & 1008 & 110 & 0.07 & 24.4 & 8887 \\
\hline & $\mathrm{T} 4$ & $225-275$ & 7.5 & 40.2 & 0.4 & 19.3 & 1.3 & 3.6 & 132 & 1.5 & 695 & 70 & 0.07 & 24.7 & 6847 \\
\hline \multicolumn{16}{|c|}{ Tailings sampling point 2} \\
\hline & $\mathrm{T} 5$ & $0-40$ & 7.8 & 28.9 & 0.6 & 14.2 & 3.1 & 5.7 & 161 & 5.8 & 665 & 72 & 0.06 & 31.9 & 5443 \\
\hline & T6 & $40-65$ & 7.8 & 38.0 & 0.1 & 22.7 & 2.0 & 1.2 & 247 & 1.1 & 1064 & 126 & 0.07 & 14.5 & 8560 \\
\hline & $\mathrm{T} 7$ & $215-250$ & 7.6 & 44.6 & 0.4 & 21.3 & 1.3 & 3.7 & 201 & 1.5 & 944 & 1 & 0.19 & 25.0 & 8600 \\
\hline \multicolumn{16}{|c|}{ Tailings sampling point 3} \\
\hline & $\mathrm{T} 8$ & $0-20$ & 7.9 & 7.2 & 0.5 & 0.13 & 2.5 & 6.4 & 13 & 6.8 & 441 & 6 & 0.06 & 34.2 & 314 \\
\hline & T9 & $60-100$ & 8.1 & 38.1 & 0.3 & 19.2 & 1.2 & 3.3 & 156 & 1.3 & 759 & 81 & 0.07 & 24.2 & 6808 \\
\hline & $\mathrm{T} 10$ & $220-240$ & 7.8 & 43.4 & 0.5 & 20.4 & 1.6 & 4.3 & 183 & 1.7 & 882 & 97 & 0.53 & 28.7 & 8131 \\
\hline \multicolumn{16}{|c|}{ Soil samples } \\
\hline & S7 & $0-15$ & 6.6 & 107.0 & 2.1 & 17.2 & 13.7 & 60.1 & 37.4 & 29.8 & 255 & 13.9 & $<0.10$ & 155.0 & 14730 \\
\hline & S11 & $0-15$ & 6.9 & 73.9 & 1.9 & 169.0 & 8.9 & 32.0 & 118.0 & 17.2 & 139 & 56.1 & 3.96 & 147.0 & 84300 \\
\hline & $\mathrm{S} 13$ & $0-15$ & 6.5 & 76.8 & 1.2 & 319.0 & 5.2 & 17.5 & 185.0 & 14.0 & 140 & 88.4 & 3.11 & 82.8 & 138482 \\
\hline
\end{tabular}

Legislative limits currently adopted in Italy for PTE concentrations in the soil, Limit 1 is intended for green and residential areas, while Limit 2 for commercial and industrial areas (Ministero dell'ambiente e della tutela del territorio e del mare, 2006, decree no. 152/06). Values above legislative limits are in bold. 


\subsection{Total and bioaccessible concentrations of PTE in the $<250 \mu \mathrm{m}$ fraction of the waste}

rock, tailings, and soil

The total concentrations of PTE for the $<250 \mu \mathrm{m}$ fraction were considerably higher than for the $<2$ mm fraction (Table 2) implying an increase in surface area and thus higher absorption of PTE to particles (Yao et al., 2015). Total As concentrations were found to be high with a maximum of 189 $\mathrm{mg} / \mathrm{kg}$. However, for all the samples, bioaccessible concentrations of As ranged from 5-33\% of total concentrations. In contrast, samples recorded BAF of Cd ranging from 72-98\%. Total concentrations of Co (5-12 mg/kg) and Cr (9-44 mg/kg) and bioaccessible concentrations (Co: 1-4 mg/kg and Cr: 1 $2 \mathrm{mg} / \mathrm{kg}$ ) were found to be low. The bioaccessible concentrations of $\mathrm{Cu}$ in waste rock, tailings and soil samples recorded mean value of $115 \mathrm{mg} / \mathrm{kg}$ (BAF 54\%), $145 \mathrm{mg} / \mathrm{kg}$ (BAF 49\%) and $65 \mathrm{mg} / \mathrm{kg}$ (BAF 41\%) respectively. Mean of total concentrations and BAF of Ni were $24 \mathrm{mg} / \mathrm{kg}$ and 33\% respectively, for all the samples.

Mean precentages of bioaccessible fractions of $\mathrm{Pb}$ in waste rock, tailings and soil samples were 32\%, $84 \%$ and $61 \%$, respectively. The waste rock samples indicated high concentrations of $\mathrm{Zn}$ with mean value of $130917 \mathrm{mg} / \mathrm{kg}$. The mean bioaccessible concentration of $\mathrm{Zn}$ in waste rock was 119461 $\mathrm{mg} / \mathrm{kg}$, resulting in BAF of $91 \%$. Similar results were obtained for tailings and soil samples, with mean value of BAF as $75 \%$ and $80 \%$ respectively. Due to the limited number of samples, statistical methods were not used for prediction of oral bioaccessible concentrations based on total concentrations. However, the Pearson's correlation coefficients conducted on samples $(n=8)$ showed strong correlation between total and bioaccessible concentrations of $\mathrm{Cd}, \mathrm{Co}, \mathrm{Cu}, \mathrm{Pb}$ and $\mathrm{Zn}$ (Supplementary material: S3).

The trend of the BAF recorded in our study was $\mathrm{Cd}(72-98 \%) \approx \mathrm{Zn}(73-94 \%)>\mathrm{Cu}(25-90 \%)>\mathrm{Pb}$ $(16-88 \%)>\mathrm{Ni}(17-60 \%)>\mathrm{Co}(24-42 \%)>\mathrm{As}(5-33 \%)>\mathrm{Cr}(3-11 \%)$. Mikutta et al. (2014) and Palumbo-Roe and Klinck (2007) reported BAF of As as 5-34\% and 0.5-42\% in mine impacted soils in Bulgaria and south England respectively, which is in close range with this study. On the other hand, samples in present study showed higher BAF for $\mathrm{Cu}$ and $\mathrm{Ni}$ compared to other mining areas (Darko 
et al., 2019; Karadaş and Kara, 2011). Furthermore, BAF for Cd, $\mathrm{Pb}$ and $\mathrm{Zn}$ in our study is comparable to those reported by Roussel et al. (2010) on smelter contaminated urban soil in northern France. Pelfrêne et al. (2012) recorded mean values of BAF in smelter contaminated agricultural soil in northern France for $\mathrm{Cd}, \mathrm{Pb}$, and $\mathrm{Zn}$ as $78 \%, 58 \%$ and $32 \%$ (here 85\%, 61\%, and 80\%, respectively). Higher bioaccessibility of $\mathrm{Zn}$ was recorded in soil in Gorno compared to agricultural soil in northern France which could be due to difference in land use. 
Table 2. Total and bioaccessible concentrations $(\mathrm{mg} / \mathrm{kg})$ and bioaccessible fraction (BAF in \%) evaluated on $<250 \mu \mathrm{m}$ size fraction.

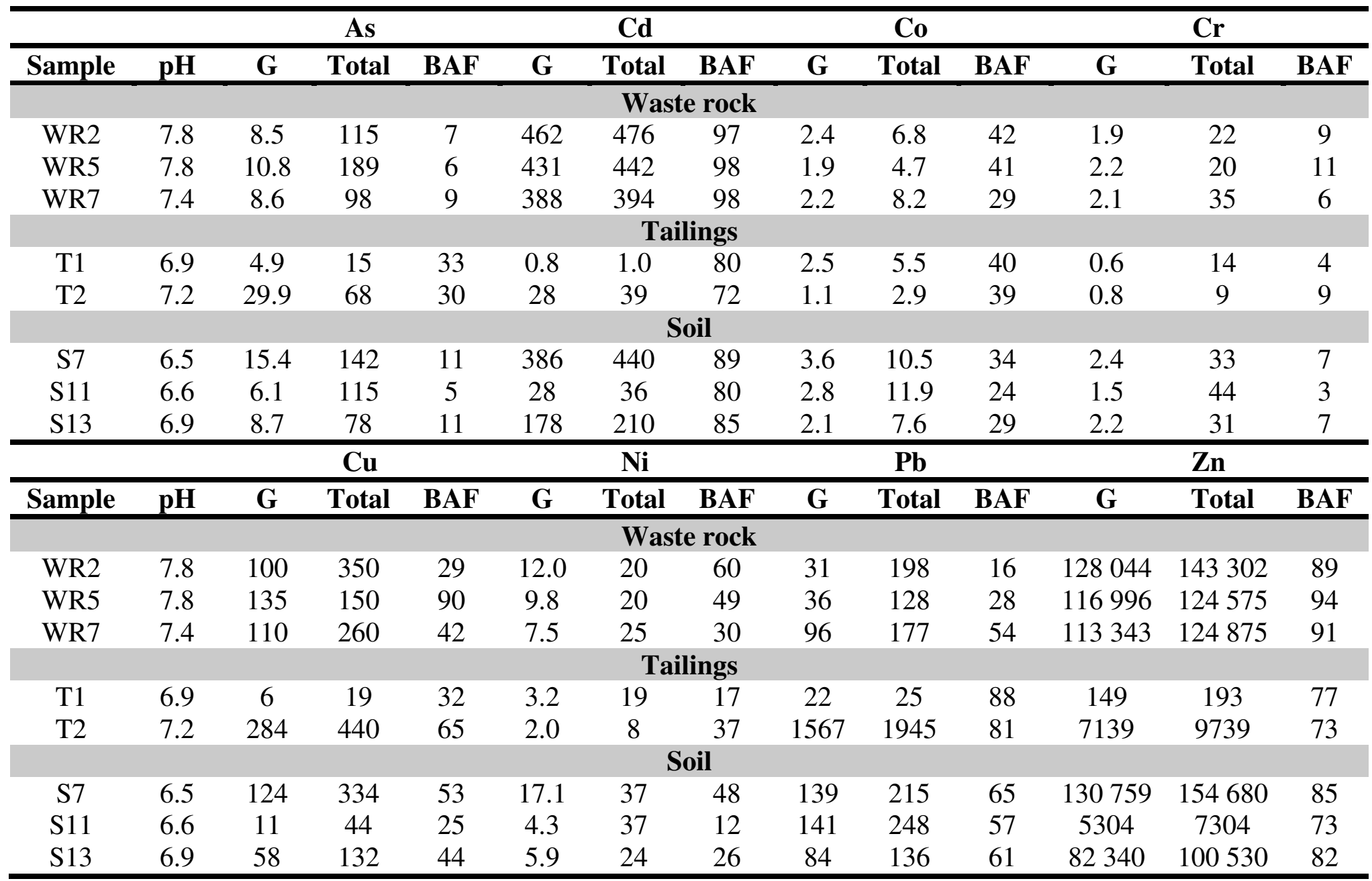

BAF: Bioaccessible fraction calculated using Eq. 1, G: concentration of PTE extracted in gastric phase of UBM; Total: total concentration of PTE using aqua regia on <250 $\mu \mathrm{m}$ fraction. 


\subsection{Solid phase distribution of the elements across waste rock, tailings, and soil matrices}

\subsubsection{Waste rock and soil}

The physico-chemical components for the most representative sample of waste rock and soil (sample codes - WR2 and S7) are in Fig.4. Heatmap for sample codes - WR5 and S13 is shown in Supplementary material: S4. Chemometric data analysis identified 7 components in waste rock sample and 9 components in the soil samples. Using the geochemical associations present at the site, six clusters were identified:

Exchangeable: This cluster in waste rock was extracted over the $\mathrm{HNO}_{3}$ concentrations of $0.01 \mathrm{M}$ to $0.05 \mathrm{M}$ and consisted of S (72\%), $\mathrm{Mg}$ (12\%), $\mathrm{Si}(5 \%)$, and $\mathrm{Zn}(4 \%)$ suggesting dissolution of sulphates present at the site (Heidel et al., 2011). The exchangeable cluster in soil consisted of (Ca-S-Mg, Ca$\mathrm{Mg}, \mathrm{Zn}, \mathrm{Zn}-\mathrm{Na}$ components), with the majority of elements being released in distilled water and 0.01 $\mathrm{M} \mathrm{HNO}_{3}$ extractant indicating that the site is rich in carbonate. The elemental composition was $\mathrm{Zn}$ (38\%), $\mathrm{Ca}(25 \%), \mathrm{Mg}(19 \%)$ and $\mathrm{S}(6 \%)$. Elevated concentrations of $\mathrm{Zn}$ and Ca indicates presence of weathered products from minerals such as smithsonite $\left(\mathrm{ZnCO}_{3}\right)$, and/or hydrozincite $\left(\mathrm{Zn}_{5}\left(\mathrm{CO}_{3}\right)_{2}(\mathrm{OH})_{6}\right)$ and hemimorphite $\left(\mathrm{Zn}_{4}\left(\mathrm{Si}_{2} \mathrm{O}_{7}\right)(\mathrm{OH})_{2} \cdot \mathrm{H}_{2} \mathrm{O}\right)$ and $\mathrm{Ca}$ rich minerals like dolomite and calcite.

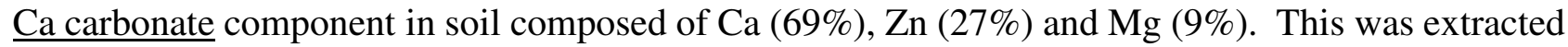
by concentrations of $\mathrm{HNO}_{3}$ ranging from $0.01 \mathrm{M}$ to $0.1 \mathrm{M}$ indicating presence of $\mathrm{Zn}$ rich minerals and calcium carbonate from the Bergamasc calcareous metalliferous lithological unit.

Site-specific: This component of waste rock comprised of $\mathrm{Zn}(74 \%), \mathrm{S}(17 \%), \mathrm{Mg}(6 \%)$ and $\mathrm{Ca}(2 \%)$. Presence of $\mathrm{Zn}$ and $\mathrm{S}$ suggests presence of oxidation products of sphalerite, zinc oxide, and sulfur rich minerals.

Higher carbonate: The extraction of waste rock at $0.1 \mathrm{M} \mathrm{HNO}_{3}$ resulted in a higher carbonates component principally consisting of S (41\%), $\mathrm{Mg}(30 \%), \mathrm{Mn}(14 \%), \mathrm{Zn}(12 \%), \mathrm{Ca}(1 \%)$ and a minor percentage of Fe. The presence of $\mathrm{Ca}-\mathrm{Fe}-\mathrm{Mg}-\mathrm{Mn}$ implies dissolution of ankerite present as gangue 
mineral in the site. The higher carbonate component in soil principally consisted of $\mathrm{Ca}(59 \%)$ and $\mathrm{Zn}$ (30\%) and was extracted at $0.1 \mathrm{M} \mathrm{HNO}_{3}$.

Pb dominated component consisted of S (54\%), $\mathrm{Mg}(37 \%), \mathrm{Zn}(4 \%)$ and $\mathrm{Ca}(3 \%)$ in waste rock. Lead concentration in this component was highest and equal to $77 \%$ of total CISED extracted $\mathrm{Pb}$. This could be due to the occurrence of galena $(\mathrm{PbS})$, which was present with sphalerite in minor association. The $\mathrm{Pb}$ dominated cluster in soil had high percentage of $\mathrm{Ca}(55 \%), \mathrm{Zn}(27 \%), \mathrm{Mg}(9 \%)$. The lead concentration in this cluster was $91 \%$, while the other components in total consisted only $9 \%$ of $\mathrm{Pb}$.

Fe oxide: The Fe oxide cluster of waste rock comprised of $\mathrm{Zn}(57 \%), \mathrm{S}$ (25\%), Mg (12\%) and Fe (3\%) and extracted by acid concentration of $1 \mathrm{M}$ to $5 \mathrm{M} \mathrm{HNO}_{3}$ and $\mathrm{H}_{2} \mathrm{O}_{2}$. This component in soil consisted of $\mathrm{Zn}(85 \%), \mathrm{Fe}(4 \%)$ and $\mathrm{Mg}(4 \%)$. The cluster recorded highest Fe concentrations and PTE extracted during the CISED extractions of both waste rock and soil samples. This was expected as digestion in the last step results in dissolution of oxides.

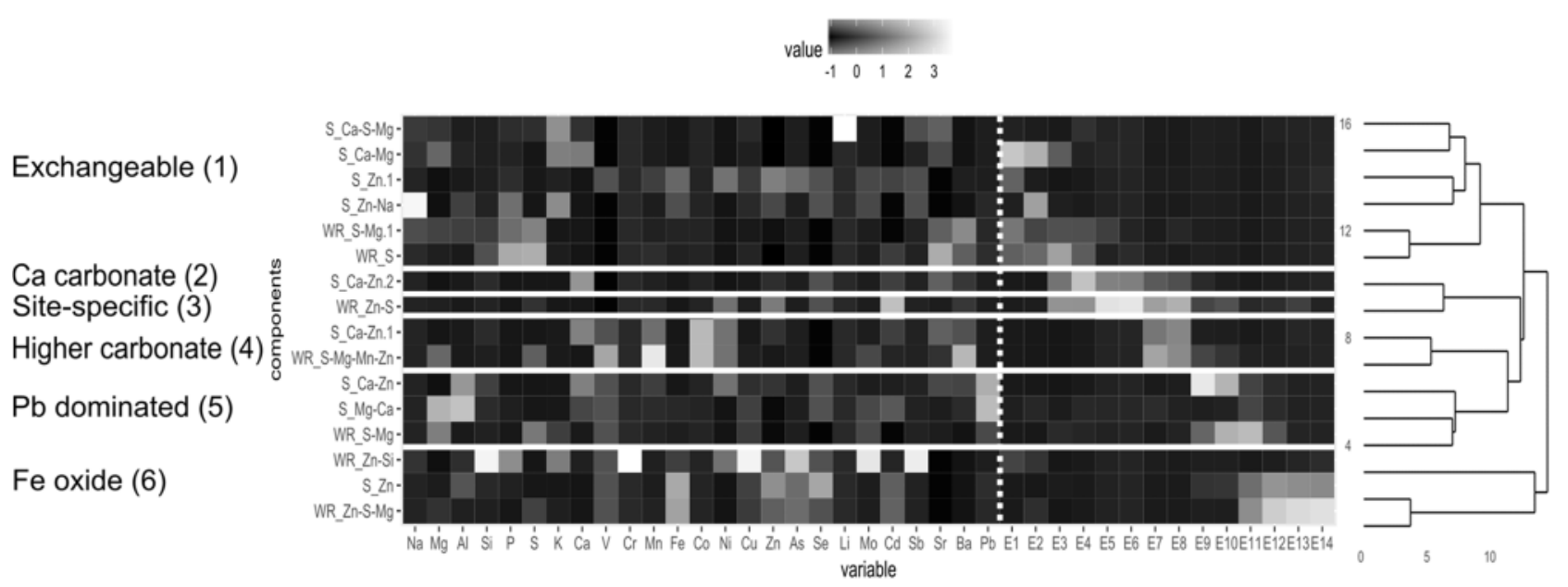

Fig.4. Heatmap and clustergram for CISED extracted WR and soil sample (sample code - WR2 and S7) of Gorno. The linkage between the components is shown in the dendrogram on the right-hand side. Elemental composition data is on the left-hand side separated with a dashed vertical white line from the extraction number data $(\mathrm{E} 1-14)$ on the right. The horizontal lines are used for dividing geochemical clusters. High concentrations are depicted by white/light grey and low concentrations by dark grey/black. Component names are provided with sample identification code (WR and S) along with the principal elements recorded for each component. 


\subsubsection{Tailings}

The physico-chemical components present in selected sample from tailings (code - T2) are shown in Fig.5. Tailings sample was subjected to separate chemometric data analysis, as tailings were generated after processing of natural minerals, which led to variation in quantities and mobility of elements when compared to waste rocks and soil. It was observed that CISED extracted samples for tailings contained higher percentages of $\mathrm{Na}$, as sodium based reagents were used for flotation. The components of tailings sample (code - T1) are in Supplementary material: S5.

The pore-water component consisted of $\mathrm{Na}, \mathrm{K}$, and $\mathrm{Pb}$ and was mainly extracted by deionised water. The Ca-carbonate cluster (Ca: $92 \%$ ) was extracted from $0.5 \mathrm{M}$ to $1 \mathrm{M}$, this is because the carbonate form is a loosely bound phase and liable to change with environmental conditions (Filgueiras et al., 2002). The higher carbonate consisted of $\mathrm{Ca}(96 \%)$. The presence of carbonates could be due to dissolution of calcite and dolomite present at the site (Dino et al., 2018).

The Fe oxide component was principally formed by $\mathrm{Mg}, \mathrm{S}$, and Fe. It was extracted in concentrations of $\mathrm{HNO}_{3}$ ranging from $1 \mathrm{M}$ to $5 \mathrm{M}$. The component consisted the majority of $\mathrm{Fe}(94 \%)$ released during CISED extractions, due to presence of weathering product of Fe sulphate observed in mineralogical analysis (Dino et al., 2018).

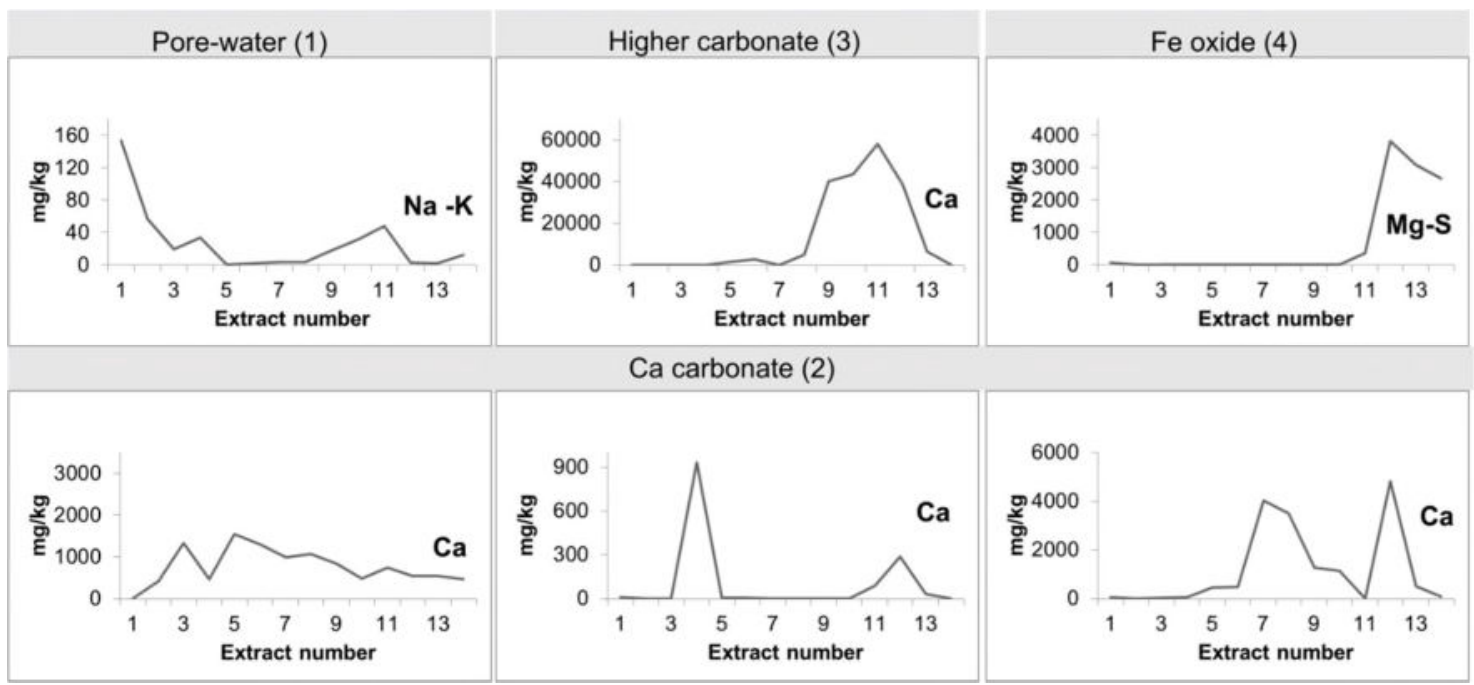

Fig.5. Extraction profiles obtained during CISED extractions of tailings (sample code - T2). 


\subsection{Comparing solid phase distribution and oral bioaccessibility for integrated assessment}

Fig.6. exhibits the concentrations of $\mathrm{As}, \mathrm{Cd}, \mathrm{Pb}$ and $\mathrm{Zn}$ extracted in each $\mathrm{CISED}$ component and the bioaccessible concentration of elements. Dissolution of Fe oxide components contributed to the bioaccessible fractions of As. Bioaccessibility values of As in all samples were recorded to be low compared to total concentrations due to strong association between $\mathrm{As}$ and $\mathrm{Fe}$ oxides and $\mathrm{Fe}$ hydroxides (exposed in Section 3.1). This is also evidenced in Fig. 6a, where As is extracted in the Fe oxide fractions of CISED

Dissolution of site-specific and Fe oxide components led to the bioaccessibility fractions of $\mathrm{Cd}$ and $\mathrm{Zn}$ in waste rock. Whilst, dissolution of $\mathrm{Pb}$ dominated and $\mathrm{Fe}$ oxide components contributed to significantly high bioaccessible concentrations of $\mathrm{Cd}$ and $\mathrm{Zn}$ in soil. The $\mathrm{Cd}$ and $\mathrm{Zn}$ bioaccessible concentrations in tailings sample were contributed by higher carbonate components of CISED extractions. The bioaccessible concentrations of $\mathrm{Cd}$ and $\mathrm{Zn}$ were high due to: (1) The calcareous geological context of area with high $\mathrm{pH}$. Mineral phases that form under alkaline conditions tend to be less stable in the acidic conditions of the stomach and more bioaccessible (Ruby et al., 1999); and (2) Weathering of sulphide minerals in the presence of oxygen can result in speciation changes and the formation of secondary mineral phases that often have greater mobility than the parent sulphide minerals (Schaider et al., 2007). In contrast, the bioaccessible fraction for As was much less compared to $\mathrm{Cd}$ and $\mathrm{Zn}$; demonstrating that even though all elements were present in the same geological context, the differences in BAF may occur due to associations of these metals with different minerals. It was observed that partial dissolution of $\mathrm{Pb}$ dominated clusters in waste rock and soil resulted in bioaccessible fractions of $\mathrm{Pb}$. Lead, showed lesser concentrations during UBM extractions than CISED. It has been demonstrated that, the dissolution of greater amounts of carbonates by the acidic gastric solutions can result in an increase of hydroxy carbonate anions available in solution, and that under such conditions, Pb can form insoluble compounds with the anions (Reis et al., 2014). 
(a)

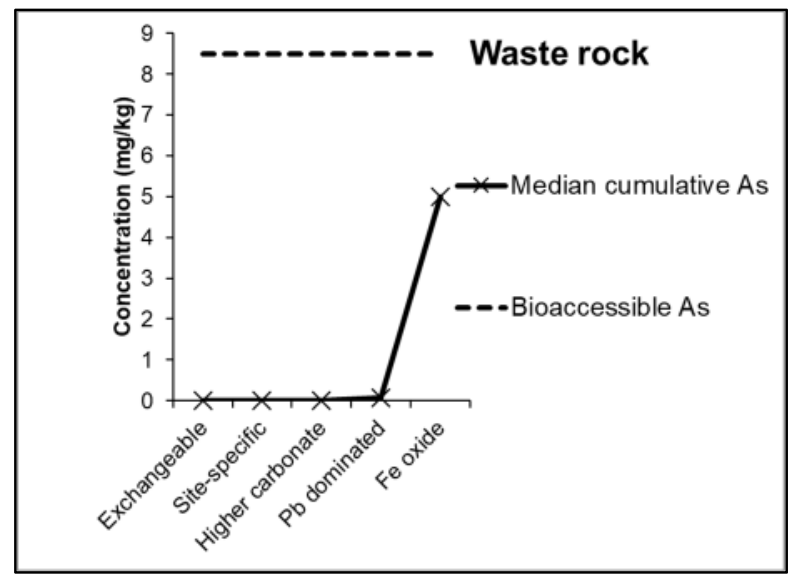

(c)

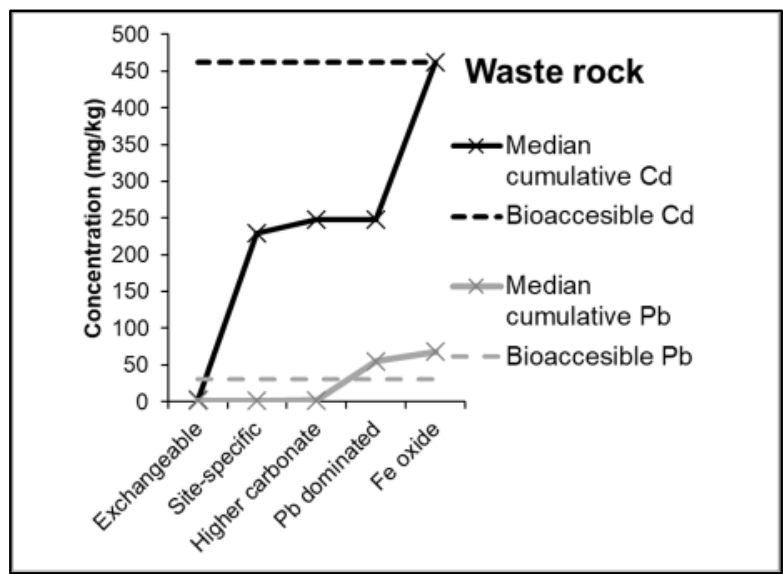

(e)

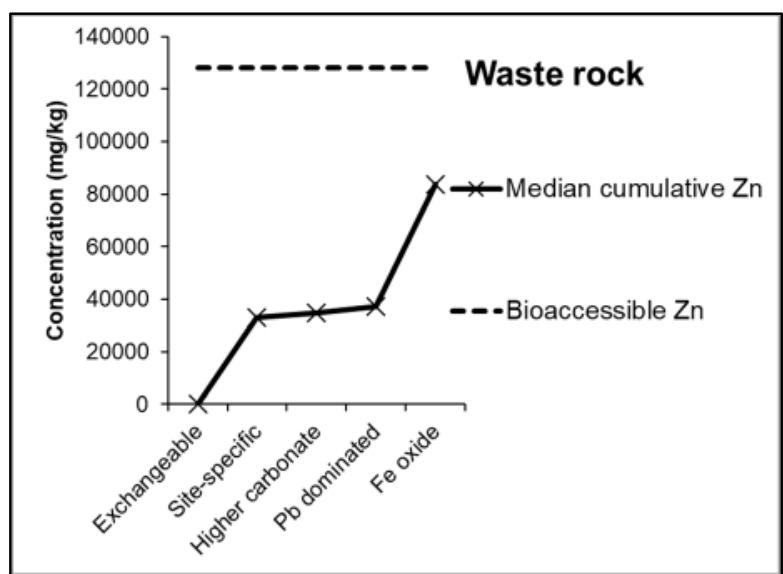

(g)

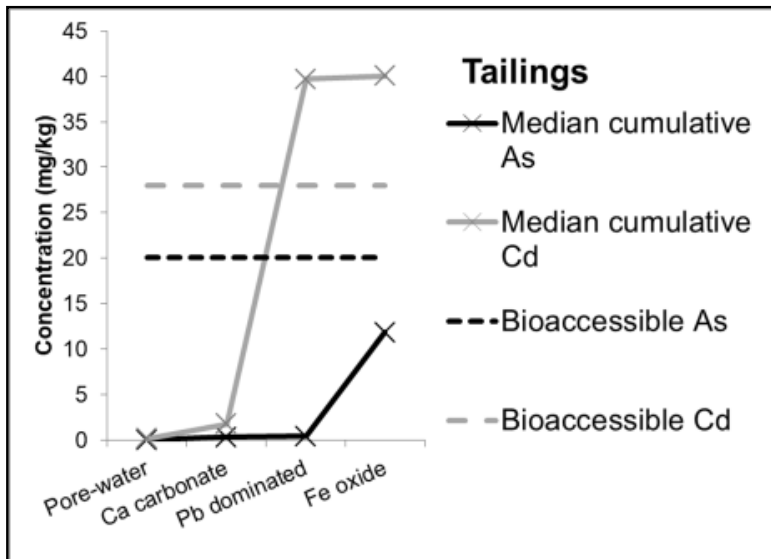

(b)

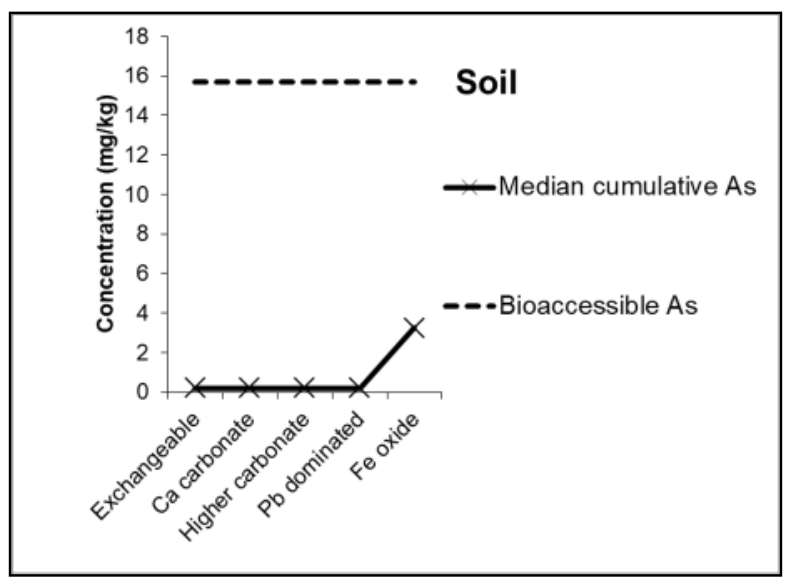

(d)

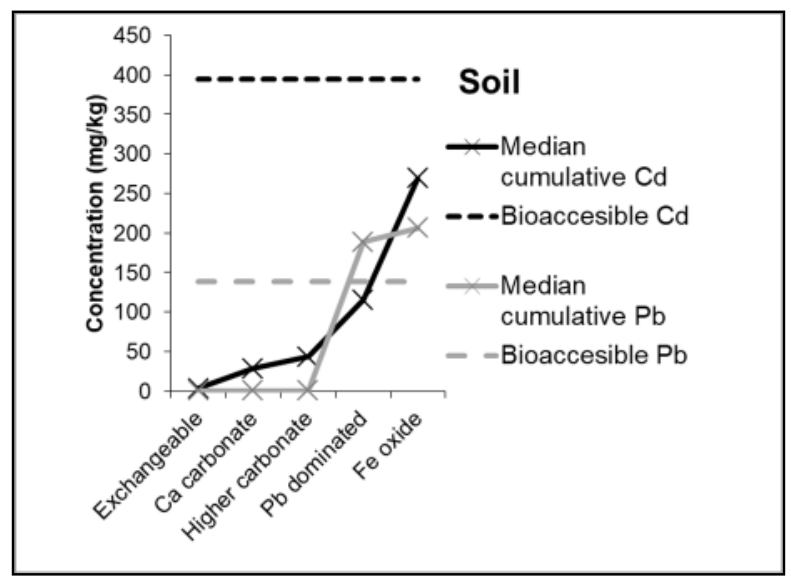

(f)

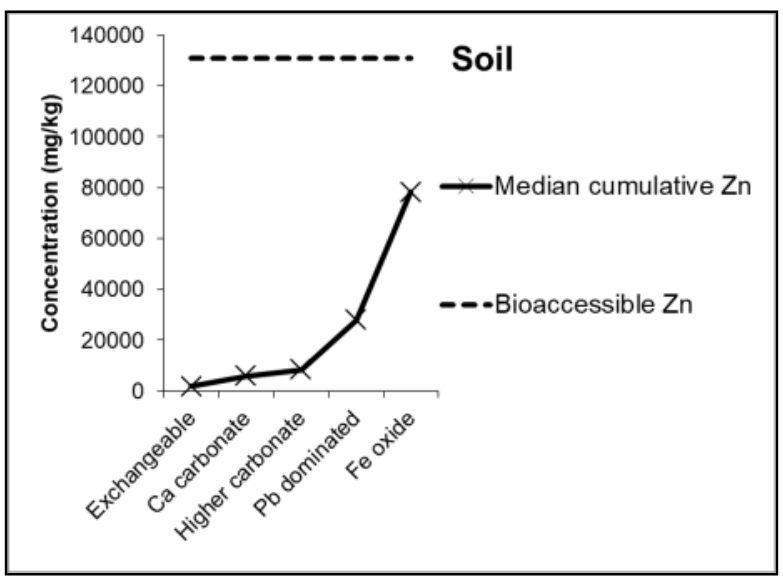

(h)

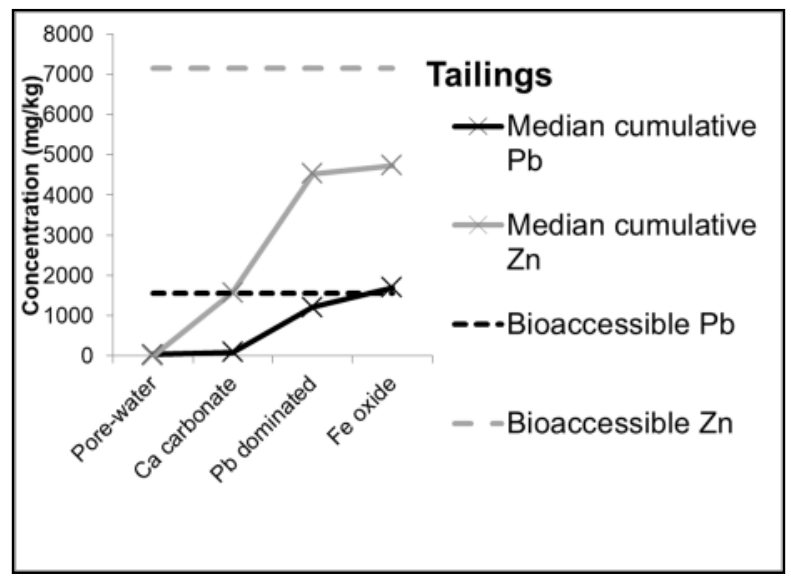


Fig.6. Median cumulative concentration in CISED extracted components (X-axis) and bioaccessible concentrations of potentially toxic elements $(\mathrm{mg} / \mathrm{kg})$. Bioaccessible: Bioaccessible concentrations, As: arsenic, $\mathrm{Cd}$ : cadmium, $\mathrm{Pb}$ : lead, $\mathrm{Zn}$ : zinc

\subsection{Human health risk assessment for ingestion}

The non-carcinogenic HQ estimations were performed for $\mathrm{As}, \mathrm{Cd}, \mathrm{Co}, \mathrm{Cr}, \mathrm{Cu}, \mathrm{Ni}, \mathrm{Pb}$ and $\mathrm{Zn}$. For residential exposure scenario, the $\mathrm{HI}$ defined as the summation of $\mathrm{HQ}$, reached to a maximum of 25.4 considering total concentrations and to a maximum of 17.9 utilising bioaccessible concentrations (Fig. 7a). The carcinogenic risk evaluated for $\mathrm{As}$ and $\mathrm{Pb}$ implied that total cancer risk i.e. $\mathrm{CR}_{\text {total }}$ reached a maximum of $4.4 \times 10^{-4}$ which is greater than $1 \times 10^{-5}$, demonstrating carcinogenic risk for total concentrations. For bioaccessible concentrations the maximum value was $2.7 \times 10^{-5}$.

For the recreational scenario, it was observed that maximum HI for total and bioaccessible concentrations were 2.0 and 1.4, respectively (Fig. 7c). The results also indicated that the site surrounding T1, T2, S11, S13 had HI <1 (acceptable level), for bioaccessible concentrations, implying no potential non-carcinogenic risks. All the samples recorded $\mathrm{CR}_{\text {total }}<1 \times 10^{-5}$ (acceptable level) using bioaccessible concentrations. This indicates that incorporating bioaccessible concentrations in HHRA refined the risk assessment process, resulting in no unacceptable carcinogenic risks being identified at all the sampling points and absence of unacceptable potential non-carcinogenic risks at half of the sampling points, as the $\mathrm{HI}$ and $\mathrm{CR}_{\mathrm{total}}$ decreased by $34 \%$ and $93 \%$ respectively.

It should be noted that all the risk calculations were performed using concentrations on size fraction $<250 \mu \mathrm{m}$ for consistency and because this is the fraction that remains adhered to skin for accidental ingestion. However the present study also reported lower total concentrations for size fraction $<2 \mathrm{~mm}$ than $<250 \mu \mathrm{m}$ (Section 3.2 and 3.3), implying that there could be underestimation of potential risk, for oral pathway, if the calculations are based on size fraction $<2 \mathrm{~mm}$. Because of the influence of soil particle size on total concentrations, soil particle size should be chosen properly for HHRA to avoid under- or overestimating human health risk (Cao et al., 2020). It is also recommend that for 
incorporation of oral bioaccessibility in HHRA, consistent particle size and samples should be analysed. This is also in line with the approach used by Luo et al. (2012) and Cao et al. (2020) where samples were first analysed for total concentrations and then the same samples were used for bioaccessibility.

The limitations of the present study were that (1) the limited number of samples collected from the abandoned mine site hindered the use of a simple linear regression model for predicting bioaccessible concentrations of PTE; (2) all samples were not analysed for mineralogy and solid phase distribution. However, the conclusions drawn from the present study were in confirmation with oral bioaccessibility and mineralogy studies conducted elsewhere (Reis et al., 2014; Ruby et al., 1999; Schaider et al., 2007). Nevertheless, the present study demonstrated that for robust decision making, role of bioaccessibility in HHRA should not be underestimated as noted by differences in potential risks due to total and bioaccessible concentrations in the HHRA framework.

(a)

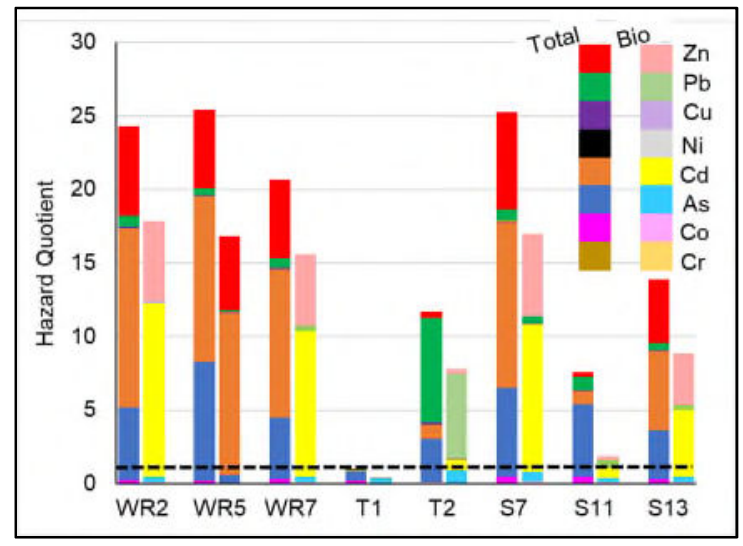

(c)

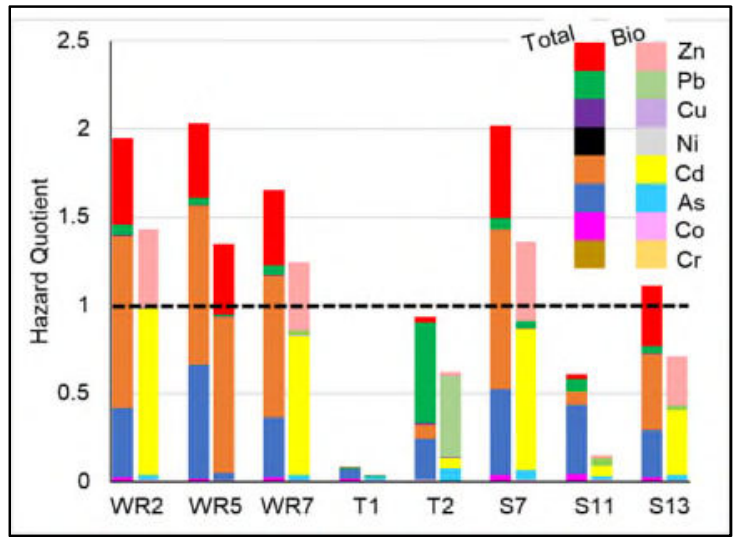

(b)

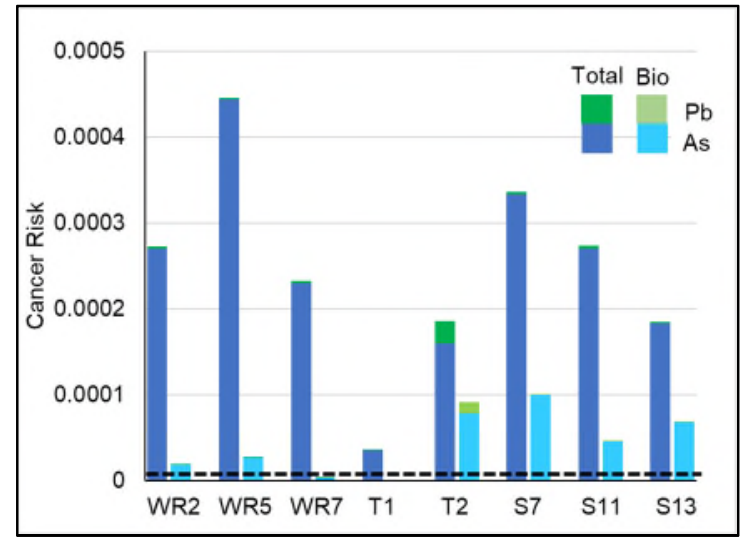

(d)

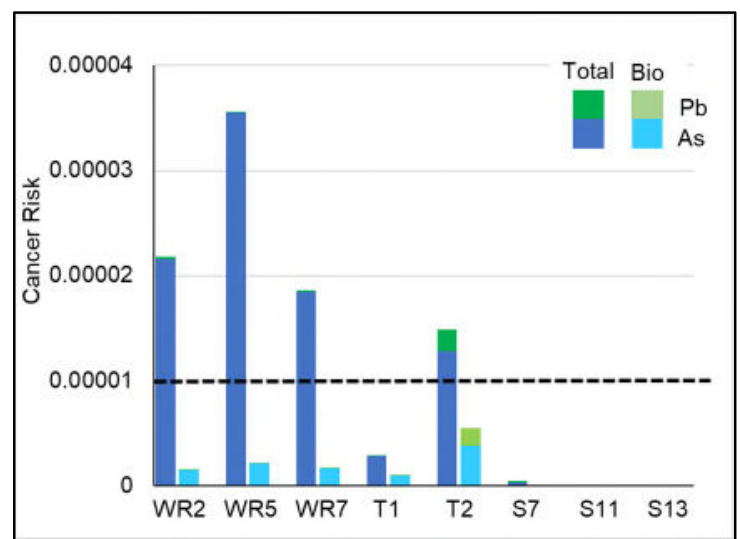

Fig.7. Human health risk for oral ingestion pathway, considering total and bioaccessible concentrations (sieved to $<250 \mu \mathrm{m}$ ). Sample identification codes are on $\mathrm{X}$-axis, and the potential risk values below the dashed black line on the $\mathrm{Y}$-axis of the graph shows the risk values within acceptable 
levels. (a) Hazard quotient for residential scenario; (b) Cancer risk for residential scenario; (c) Hazard quotient considering recreation scenario; and (d) Cancer risk considering recreation scenario.

\section{Conclusions}

This paper has highlighted the importance of assessing site-specific oral bioaccessibility to provide improved estimates of human health risks from exposure to PTE in abandoned mine sites. Waste rock, tailings and soil samples had strong enrichment of PTE in Gorno, northwest Italy. The total PTE concentrations were higher in the $<250 \mu \mathrm{m}$ fraction than in the $<2 \mathrm{~mm}$ fraction, implying higher specific surface area for smaller size fractions. The range of oral BAF across samples was observed as: As (5-33\%), Cd (72-98\%), Co (24-42\%), Cr (3-11\%), Cu (25-90\%), Ni (17-60\%), Pb (16-88\%), and $\mathrm{Zn} \mathrm{(73-94 \% ).} \mathrm{Solid} \mathrm{phase} \mathrm{distribution} \mathrm{and} \mathrm{mineralogical} \mathrm{analysis} \mathrm{demonstrated} \mathrm{that} \mathrm{pH}$; geological and lithological properties; and presence of carbonatic minerals influenced oral bioaccessibility.

Oral bioaccessibility analyis concluded that PTE are not fully bioaccessible, which implies that use of total concentrations is not adequate in determining the actual risk associated. Incorporation of sitespecific BAF values showed decrease in potential non-carcinogenic and carcinogenic risks by $34 \%$ and $93 \%$ respectively for ingestion pathway. Thus, bioaccessibility-corrected HHRA reduces the uncertainty associated with the human exposure estimates and the extent of required remediation efforts. The approach provided in this study, based on bioaccessibility-correction and RBCA guidelines, can be used in estimating hazards associated with exposures to PTE in soils near abandoned mine sites.

\section{CRediT author statement}

Neha Mehta: Conceptualization, Investigation, Writing - original draft, Visualization, Formal analysis. Sabrina Cipullo: Software, Methodology, Formal analysis. Tatiana Cocerva: Investigation, Methodology, Formal Analysis. Frederic Coulon: Supervision, Writing - review \& 
editing. Giovanna Antonella Dino: Funding, Writing - review \& editing. Franco Ajmone-Marsan: Funding, Supervision, Writing - review \& editing. Elio Padoan: Investigation, Writing - review \& editing. Siobhan Fiona Cox: Supervision, Writing - review \& editing. Mark R Cave: Writing review \& editing. Domenico Antonio De Luca: Funding, Supervision, Writing - review \& editing.

\section{Acknowledgments}

This work was completed as part of the REMEDIATE (Improved decision-making in contaminated land site investigation and risk assessment) Marie-Curie Innovation Training Network. The network has received funding from the European Union's Horizon 2020 Programme for research, technological development and demonstration under grant agreement n. 643087. Authors also express gratitude towards: Giorgio Carbotta for helping with sampling, Dr Jie Chen for analysing mineralogy using micro-XRF and SEM, Dr Christophe Real for providing bibliography related to geology of the site, Dr Thomas King for proofreading the manuscript, and Prof. Piergiorgio Rossetti for teaching Petromod from Department of Earth Sciences, University of Torino, Italy.

\section{References}

Acero, P., Cama, J., and Ayora, C. (2007). Sphalerite dissolution kinetics in acidic environment. Appl. Geochem. 22, 1872-1883.

Adimalla, N. (2019). Controlling factors and mechanism of groundwater quality variation in semiarid region of South India: an approach of water quality index (WQI) and health risk assessment (HRA). Environ. Geochem. Health, https://doi.org/10.1007/s10653-019-00374-8.

Anju, M., and Banerjee, D.K. (2011). Associations of cadmium, zinc, and lead in soils from a lead and zinc mining area as studied by single and sequential extractions. Environ. Monit. Assess. 176, 67-85. 
APAT-ISPRA (2008). Criteri Metodologici l'Applicazione dell'Analisi Assoluta di Rischio ai Siti Ccontaminati. Avaliable at http://www.isprambiente.gov.it/it/archivio/eventi/anno2005/manualirischiositicontaminati, accessed 21/10/2019.

ASTM, E1739-95e1, 1995. Standard Guide for Risk Based Corrective Action Applied at Petroleum Release Sites. ASTM International, West Conshohocken, PA.

ASTM, E2081-00, 2015. Standard Guide for Risk Based Corrective Action. ASTM International, West Conshohocken, PA.

BARGE (2010). UBM Procedure for the Measurement of the Inorganic Contaminant Bioaccessibility from Solid Matrices.

Beauchemin, S., Rasmussen, P.E., MacKinnon, T., Chénier, M., and Boros, K. (2014). Zinc in house dust: speciation, bioaccessibility, and impact of humidity. Environ. Sci. Technol. 48, 9022-9029.

Beltrando, M., Stockli, D.F., Decarlis, A., and Manatschal, G. (2015). A crustal-scale view at rift localization along the fossil Adriatic margin of the Alpine Tethys preserved in NW Italy. Tectonics. $34,9,1927-1951$.

Bharadwaj, L., and Machibroda, R. (2008). Human health risk assessment approach for urban park development. Arh. Hig. Rada Toksikol. 59, 213-221.

Boente, C., Martín-Méndez, I., Bel-Lán, A., and Gallego, J.R. (2020). A novel and synergistic geostatistical approach to identify sources and cores of potentially toxic elements in soils: an application in the region of Cantabria (Northern Spain). J. Geochem. Explor. 208, 106397.

Boim, A.G.F., Wragg, J., Canniatti-Brazaca, S.G., and Alleoni, L.R.F. (2019). Human intestinal Caco-2 cell line in vitro assay to evaluate the absorption of $\mathrm{Cd}, \mathrm{Cu}, \mathrm{Mn}$ and $\mathrm{Zn}$ from urban environmental matrices. Environ. Geochem. Health, https://doi.org/10.1007/s10653-019-00394-4.

Bradham, K.D., Green, W., Hayes, H., Nelson, C., Alava, P., Misenheimer, J., Diamond, G.L., Thayer, W.C., and Thomas, D.J. (2016). Estimating relative bioavailability of soil lead in the mouse. J. Toxicol. Environ. Health A 79, 1179-1182. 
Brattin, W., and Casteel, S. (2013). Measurement of arsenic relative bioavailability in swine. J. Toxicol. Environ. Health A 76, 449-457.

BRGM (2001). Management of Mining, Quarrying and Ore-processing Waste in the European Union. In: Proceedings of the European Commission Co-ordination by P. Charbonnier on Study made for DG Environment. December 2001. BRGM/RP-50319- FR. 88. Available at https://ec.europa.eu/environment/waste/studies/mining/0204finalreportbrgm.pdf, $\quad$ accessed $03 / 01 / 2020$

Bullock, L.A., Parnell, J., Feldmann, J., Armstrong, J.G., Henn, A.S., Mesko, M.F., Mello, P.A., and Flores, E.M.M. (2019). Selenium and tellurium concentrations of Carboniferous British coals. Geol. J. 54, 1401-1412.

Cao, P., Fujimori, T., Juhasz, A., Takaoka, M., and Oshita, K. (2020) Bioaccessibility and human health risk assessment of metal(loid)s in soil from an e-waste open burning site in Agbogbloshie, Accra, Ghana. Chemosphere, 240, 124909.

Casteel, S. W., Weis Christopher P., Henningsen Gerry M., and Brattin William J. (2006). Estimation of relative bioavailability of lead in soil and soil-like materials using young swine. Environ. Health Perspect. 114, 1162-1171.

Cave, M. R., Milodowski, A. E., \& Friel, E. N. (2004). Evaluation of a method for identification of host physicochemical phases for trace metals and measurement of their solid-phase partitioning in soil samples by nitric acid extraction and chemometric mixture resolution. Geochem. Explor. Environ. Anal. 4, 71-86.

CIEH (2009). Professional Practice Note: Reviewing Human Health Risk Assessment Reports Invoking Contaminant Oral Bioavailability Measurements Or Estimates. Chartered Institute of Environmental Health (CIEH).

Cipullo, S., Snapir, B., Tardif, S., Campo, P., Prpich, G., and Coulon, F. (2018). Insights into mixed contaminants interactions and its implication for heavy metals and metalloids mobility, bioavailability and risk assessment. Sci. Total Environ. 645, 662-673. 
Clark, M.W., Walsh, S.R., and Smith, J.V. (2001). The distribution of heavy metals in an abandoned mining area; a case study of Strauss Pit, the Drake mining area, Australia: implications for the environmental management of mine sites. Environ. Geol. 40, 655-663.

Cossio, R., Borghi, A., and Ruffini, R. (2002). Quantitative modal determination of geological samples based on X-ray multielemental map acquisition. Microsc. Microanal. 8, 139-149.

Cox, S.F., Chelliah, M.C.M., McKinley, J.M., Palmer, S., Ofterdinger, U., Young, M.E., Cave, M.R., and Wragg, J. (2013). The importance of solid-phase distribution on the oral bioaccessibility of Ni and $\mathrm{Cr}$ in soils overlying Palaeogene basalt lavas, Northern Ireland. Environ. Geochem. Health 35, $553-567$.

Damian, G., Andráš, P., Damian, F., Turisová, I., and Iepure, G. (2018). The role of organo-zeolitic material in supporting phytoremediation of a copper mining waste dump. Int. J. Phytoremediation 20, $1307-1316$.

Darko, G., Boakye, K.O., Nkansah, M.A., Gyamfi, O., Ansah, E., Yevugah, L.L., Acheampong, A., and Dodd, M. (2019). Human health risk and bioaccessibility of toxic metals in topsoils from Gbani mining community in Ghana. J. Health Pollut. 9, 190602.

Das, P., Samantaray, S., and Rout, G.R. (1997). Studies on cadmium toxicity in plants: a review. Environ. Pollut. 98, 29-36.

Delil, A.D., and Köleli, N. (2019). Investigation of a combined continuous flow system for the removal of $\mathrm{Pb}$ and $\mathrm{Cd}$ from heavily contaminated soil. Chemosphere 229, 181-187.

Denys, S., Caboche, J., Tack, K., Rychen, G., Wragg, J., Cave, M., Jondreville, C., and Feidt, C. (2012). In vivo validation of the Unified BARGE Method to assess the bioaccessibility of arsenic, antimony, cadmium, and lead in soils. Environ. Sci. Technol. 46, 6252-6260.

Denys, S., Tack, K., Caboche, J., and Delalain, P. (2009). Bioaccessibility, solid phase distribution, and speciation of $\mathrm{Sb}$ in soils and in digestive fluids. Chemosphere 74, 711-716.

De Souza, M.R., da Silva, F.R., de Souza, C.T., Niekraszewicz, L., Dias, J.F., Premoli, S., Corrêa, D.S., Soares, M. do C., Marroni, N.P., Morgam-Martins, M.I., et al. (2015). Evaluation of the 
genotoxic potential of soil contaminated with mineral coal tailings on snail Helix aspersa. Chemosphere 139, 512-517.

Dino, G.A., Rossetti, P., Perotti, L., Alberto, W., Sarkka, H., Coulon, F., Wagland, S., Griffiths, Z., and Rodeghiero, F. (2018). Landfill mining from extractive waste facilities: the importance of a correct site characterisation and evaluation of the potentialities. A case study from Italy. Resour. Policy. 59, 55-61.

Du, H., Yin, N., Cai, X., Wang, P., Li, Y., Fu, Y., Sultana, Mst.S., Sun, G., and Cui, Y. (2020). Lead bioaccessibility in farming and mining soils: the influence of soil properties, types and human gut microbiota. Sci. Total Environ. 708, 135227.

Edokpayi, J.N., Machaba, H.I., Ogombe, H.S., and Odiyo, J.O. (2016). Evaluation of contamination of soil by trace metals from dairy wastewater in Limpopo province, South Africa. Der Pharma Chemica 8(7):16-24.

Ettler, V., Cihlová, M., Jarošíková, A., Mihaljevič, M., Drahota, P., Křribek, B., Vaněk, A., Penížek, V., Sracek, O., Klementová, M., et al. (2019). Oral bioaccessibility of metal(loid)s in dust materials from mining areas of northern Namibia. Environ. Int. 124, 205-215. Ettler, V., Polák, L., Mihaljevič, M., Ratié, G., Garnier, J., and Quantin, C. (2018). Oral bioaccessibility of inorganic contaminants in waste dusts generated by laterite Ni ore smelting. Environ. Geochem. Health 40, 1699-1712.

Fernández-Caliani, J.C., Giráldez, M.I., and Barba-Brioso, C. (2019). Oral bioaccessibility and human health risk assessment of trace elements in agricultural soils impacted by acid mine drainage. Chemosphere 237, 124441.

Filgueiras, A.V., Lavilla, I., and Bendicho, C. (2002). Chemical sequential extraction for metal partitioning in environmental solid samples. J. Environ. Monit. 4, 823-857.

Foulkes, M., Millward, G., Henderson, S., and Blake, W. (2017). Bioaccessibility of U, Th and Pb in solid wastes and soils from an abandoned uranium mine. J. Environ. Radioact. 173, 85-96.

Gerba, C.P. (2009). Risk Assessment in Environmental Microbiology. Elsevier Inc., pp. 575-587. 
González-Grijalva, B., Meza-Figueroa, D., Romero, F.M., Robles-Morúa, A., Meza-Montenegro, M., García-Rico, L., and Ochoa-Contreras, R. (2019). The role of soil mineralogy on oral bioaccessibility of lead: implications for land use and risk assessment. Sci. Total Environ. 657, 1468-1479.

Hamilton, E.M., Barlow, T.S., Gowing, C.J.B., and Watts, M.J. (2015). Bioaccessibility performance data for fifty-seven elements in guidance material BGS 102. Microchem. J. 123, 131-138.

Heidel, C., Tichomirowa, M., and Breitkopf, C. (2011). Sphalerite oxidation pathways detected by oxygen and sulfur isotope studies. Appl. Geochem. 26, 2247-2259.

Hou, Y., Azmy, K., Berra, F., Jadoul, F., Blamey, N.J.F., Gleeson, S.A., and Brand, U. (2016). Origin of the Breno and Esino dolomites in the western Southern Alps (Italy): implications for a volcanic influence. Mar. Pet. Geol. 69, 38-52.

ISO 10390:2005. Soil Quality - Determination of pH. 7 pp. Available at https://www.iso.org/standard/40879.html.

ISO 17924:2018. Soil quality - Assessment of human exposure from ingestion of soil and soil material - Procedure for the estimation of the human bioaccessibility/bioavailability of metals in soil.

Jain, A., Raven, K.P., and Loeppert, R.H. (1999). Arsenite and arsenate adsorption on ferrihydrite: surface charge reduction and net $\mathrm{OH}^{-}$release stoichiometry. Environ. Sci. Technol. 33, 1179-1184. Juhasz, A.L., Weber, J., Naidu, R., Gancarz, D., Rofe, A., Todor, D., and Smith, E. (2010). Determination of cadmium relative bioavailability in contaminated soils and its prediction using in vitro methodologies. Environ. Sci. Technol. 44, 5240-5247.

Kang, Y., Pan, W., Liang, S., Li, N., Zeng, L., Zhang, Q., and Luo, J. (2016). Assessment of relative bioavailability of heavy metals in soil using in vivo mouse model and its implication for risk assessment compared with bioaccessibility using in vitro assay. Environ. Geochem. Health 38, 11831191.

Karadaş, C., and Kara, D. (2011). In vitro gastro-intestinal method for the assessment of heavy metal bioavailability in contaminated soils. Environ. Sci. Pollut. Res. 18, 620-628. 
Karlsson, T., Räisänen, M.L., Lehtonen, M., and Alakangas, L. (2018). Comparison of static and mineralogical ARD prediction methods in the Nordic environment. Environ. Monit. Assess. 190, 719. Kasemodel, M.C., Papa, T.B.R., Sígolo, J.B., and Rodrigues, V.G.S. (2019). Assessment of the mobility, bioaccessibility, and ecological risk of $\mathrm{Pb}$ and $\mathrm{Zn}$ on a dirt road located in a former mining area-Ribeira Valley-Brazil. Environ. Monit. Assess. 191, 101.

Kaupilla, P.M., and Tarvainen, T. (2018). Improving the environmental properties, utilisation and long-term prediction of mining wastes. Geological Survey of Finland. Bulletin 408.

Khelifi, F., Besser, H., Ayadi, Y., Liu, G., Yousaf, B., Harabi, S., Bedoui, S., Zighmi, K., and Hamed, Y. (2019). Evaluation of potentially toxic elements' (PTEs) vertical distribution in sediments of Gafsa-Metlaoui mining basin (Southwestern Tunisia) using geochemical and multivariate statistical analysis approaches. Environ. Earth Sci. 78, 53.

Leach, D.L., Bradley, D.C., Huston, D., Pisarevsky, S.A., Taylor, R.D., and Gardoll, S.J. (2010). Sediment-hosted lead-zinc deposits in earth history. Econ. Geol. 105, 593-625.

Lis, J., Pasieczna, A., Karbowska, B., Zembrzuski, W., and Lukaszewski, Z. (2003). Thallium in soils and stream sediments of a $\mathrm{Zn}-\mathrm{Pb}$ mining and smelting area. Environ. Sci. Technol. 37, 4569-4572. Luo, X.-S., Ding, J., Xu, B., Wang, Y.-J., Li, H.-B., and Yu, S. (2012). Incorporating bioaccessibility into human health risk assessments of heavy metals in urban park soils. Sci. Total Environ. 424, 8896.

Maddaloni, M., Lolacono, N., Manton, W., Blum, C., Drexler, J., and Graziano, J. (1998). Bioavailability of soilborne lead in adults, by stable isotope dilution. Environ. Health Perspect. 106, 1589-1594.

McLennan, S.M. (2001). Relationships between the trace element composition of sedimentary rocks and upper continental crust. Geochem. Geophys. Geosystems 2.

Mehta, N., Cocerva, T., Cipullo, S., Padoan, E., Dino, G.A., Ajmone-Marsan, F., Cox, S.F., Coulon, F., and De Luca, D.A. (2019). Linking oral bioaccessibility and solid phase distribution of potentially 
toxic elements in extractive waste and soil from an abandoned mine site: case study in Campello Monti, NW Italy. Sci. Total Environ. 651, 2799-2810.

Mikutta, C., Mandaliev, P.N., Mahler, N., Kotsev, T., and Kretzschmar, R. (2014). Bioaccessibility of arsenic in mining-impacted circumneutral river floodplain soils. Environ. Sci. Technol. 48, 1346813477.

Ministero dell'ambiente e della tutela del territorio e del mare. (2006). Gazzetta Ufficiale n. 88 of 14 Aprile 2006 Decreto Legislativo 3 aprile 2006, n. 152 "Norme in materia ambientale." (Norms concerning the environment.)

Molina, R.M., Schaider, L.A., Donaghey, T.C., Shine, J.P., and Brain, J.D. (2013). Mineralogy affects geoavailability, bioaccessibility and bioavailability of zinc. Environ. Pollut. 182, 217-224.

Nakaona, L., Maseka, K.K., Hamilton, E.M., and Watts, M.J. (2019). Using human hair and nails as biomarkers to assess exposure of potentially harmful elements to populations living near mine waste dumps. Environ. Geochem. Health, https://doi.org/10.1007/s10653-019-00376-6.

Palumbo-Roe, B., and Klinck, B. (2007). Bioaccessibility of arsenic in mine waste-contaminated soils: a case study from an abandoned arsenic mine in SW England (UK). J. Environ. Sci. Health Part A $42,1251-1261$.

Paustenbach, D.J. (2000). The practice of exposure assessment: a state-of-the-art review. J. Toxicol. Environ. Health Part B 3, 179-291.

Pelfrêne, A., Waterlot, C., Mazzuca, M., Nisse, C., Cuny, D., Richard, A., Denys, S., Heyman, C., Roussel, H., Bidar, G., et al. (2012). Bioaccessibility of trace elements as affected by soil parameters in smelter-contaminated agricultural soils: a statistical modeling approach. Environ. Pollut. 160, 130138.

Petrella, A., Spasiano, D., Cosma, P., Rizzi, V., and Race, M. (2019a). Evaluation of the hydraulic and hydrodynamic parameters influencing photo-catalytic degradation of bio-persistent pollutants in a pilot plant. Chem. Eng. Commun. 206:10, 1286-1296. 
Petrella, A., Spasiano, D., Rizzi, V., Cosma, P., Race, M., and Vietro, N.D. (2019b). Thermodynamic and kinetic investigation of heavy metals sorption in packed bed columns by recycled lignocellulosic materials from olive oil production. Chem. Eng. Commun. 206:12, 1715-1730.

Reis, A.P., Patinha, C., Wragg, J., Dias, A.C., Cave, M., Sousa, A.J., Costa, C., Cachada, A., Silva, E.F. da, Rocha, F., et al. (2014). Geochemistry, mineralogy, solid-phase fractionation and oral bioaccessibility of lead in urban soils of Lisbon. Environ. Geochem. Health 36, 867-881.

Roussel, H., Waterlot, C., Pelfrêne, A., Pruvot, C., Mazzuca, M., and Douay, F. (2010). Cd, Pb and $\mathrm{Zn}$ oral bioaccessibility of urban soils contaminated in the past by atmospheric emissions from two lead and zinc smelters. Arch. Environ. Contam. Toxicol. 58, 945-954.

Ruby, M.V., Schoof, R., Brattin, W., Goldade, M., Post, G., Harnois, M., Mosby, D.E., Casteel, S.W., Berti, W., Carpenter, M., et al. (1999). Advances in evaluating the oral bioavailability of inorganics in soil for use in human health risk assessment. Environ. Sci. Technol. 33, 3697-3705.

Ruby, M.V., Davis, A., Schoof, R., Eberle, S., and Sellstone, C.M. (1996). Estimation of Lead and Arsenic Bioavailability Using a Physiologically Based Extraction Test. Environ. Sci. Technol. 30, $422-430$.

Ruby, M.V., Fehling, K.A., Paustenbach, D.J., Landenberger, B.D., and Holsapple, M.P. (2002). Oral bioaccessibility of dioxins/furans at low concentrations (50-350 ppt toxicity equivalent) in soil. Environ. Sci. Technol. 36, 4905-4911.

Schaider, L.A., Senn, D.B., Brabander, D.J., McCarthy, K.D., and Shine, J.P. (2007). Characterization of zinc, lead, and cadmium in mine waste: implications for transport, exposure, and bioavailability. Environ. Sci. Technol. 41, 4164-4171.

Stewart, A.G. (2019). Mining is bad for health: a voyage of discovery. Environ. Geochem. Health, https://doi.org/10.1007/s10653-019-00367-7.

Suh, M., Casteel, S., Dunsmore, M., Ring, C., Verwiel, A., and Proctor, D.M. (2019). Bioaccessibility and relative oral bioavailability of cobalt and nickel in residential soil and dust affected by metal grinding operations. Sci. Total Environ. 660, 677-689. 
Ullrich, S.M., Ramsey, M.H., and Helios-Rybicka, E. (1999). Total and exchangeable concentrations of heavy metals in soils near Bytom, an area of $\mathrm{Pb} / \mathrm{Zn}$ mining and smelting in Upper Silesia, Poland. Appl. Geochem. 14, 187-196.

U.S. EPA, 3051 A, Washington, DC (2007). Microwave Assisted Acid Digestion of Sediments, Sludges, Soils, and Oils.

U.S. EPA, 6010 C, Washington, DC (2007). Inductively Coupled Plasma-atomic Emission Spectrometry.

U.S. EPA, Washington, DC (1991). Calculation of Risk-based Preliminary Remediation Goals. Available at https://www.epa.gov/sites/production/files/2015-09/documents/chapt3.pdf accessed 03/01/2020.

U.S. EPA, Washington, DC (2002). Supplemental Guidance for Developing Soil Screening Levels for Superfund Sites. Document OSWER 9355.4-24, Office of Emergency and Remedial Response.

U.S. EPA, Washington, DC (2007). Guidance for Evaluating the Oral Bioavailability of Metals in Soils for Use in Human Health Risk Assessment. OSWER 9285.7-80

U.S. EPA, Washington, DC (2008). Standard Operating Procedure for an in Vitro Bioaccessibility Assay for Lead in Soil. EPA 9200.2-86

U.S. EPA, Washington, DC (2011). Exposure Factors Handbook. 2011 edition. National Technical Information Service, Springfield, VA. [EPA/600/R-09/ 052F].

U.S. EPA IRIS, Washington DC (2019). Integrated Risk Information System. Available at http://www.epa.gov/iris/ accessed 03/01/2020.

Väänänen, K., Kauppila, T., Mäkinen, J., Leppänen, M.T., Lyytikäinen, M., and Akkanen, J. (2016). Ecological risk assessment of boreal sediments affected by metal mining: metal geochemistry, seasonality, and comparison of several risk assessment methods. Integr. Environ. Assess. Manag. 12, $759-771$. 
Vallero, D.A., and Blight, G. (2019). Chapter 6 - Mine Waste: A Brief Overview of Origins, Quantities, and Methods of Storage. In Waste (Second Edition), T.M. Letcher, and D.A. Vallero, eds. (Academic Press), pp. 129-151.

Vasiluk, L., Dutton, M.D., and Hale, B. (2011). In vitro estimates of bioaccessible nickel in fieldcontaminated soils, and comparison with in vivo measurement of bioavailability and identification of mineralogy. Sci. Total Environ. 409, 2700-2706.

Vasiluk, L., Sowa, J., Sanborn, P., Ford, F., Dutton, M.D., and Hale, B. (2019). Bioaccessibility estimates by gastric SBRC method to determine relationships to bioavailability of nickel in ultramafic soils. Sci. Total Environ. 673, 685-693.

Wang, Y.-L., Tsou, M.-C., Liao, H.-T., Hseu, Z.-Y., Dang, W., Hsi, H.-C., and Chien, L.-C. (2020). Influence of soil properties on the bioaccessibility of $\mathrm{Cr}$ and $\mathrm{Ni}$ in geologic serpentine and anthropogenically contaminated non-serpentine soils in Taiwan. Sci. Total Environ. 714, 136761.

Wilson, S.C., Lockwood, P.V., Ashley, P.M., and Tighe, M. (2010). The chemistry and behaviour of antimony in the soil environment with comparisons to arsenic: a critical review. Environ. Pollut. 158, 1169-1181.

Wragg, J., Cave, M., Basta, N., Brandon, E., Casteel, S., Denys, S., Gron, C., Oomen, A., Reimer, K., Tack, K., et al. (2011). An inter-laboratory trial of the unified BARGE bioaccessibility method for arsenic, cadmium and lead in soil. Science of The Total Environment 409, 4016-4030.

Yan-Chu, H. (1994). Arsenic distribution in soils, in: Nriagu, J. O. (Ed.), Arsenic in the Environment, Part 1: Cycling and Characterisation, John Wiley \& Sons, (Inc 1994), pp.17-49.

Yang, S., Li, P., Liu, J., Bi, X., Ning, Y., Wang, S., and Wang, P. (2019). Profiles, source identification and health risks of potentially toxic metals in pyrotechnic-related road dust during Chinese new year. Ecotoxicol. Environ. Saf. 184, 109604.

Yao, Q., Wang, X., Jian, H., Chen, H., and Yu, Z. (2015). Characterization of the Particle Size Fraction associated with Heavy Metals in Suspended Sediments of the Yellow River. Int. J. Environ. Res. Public. Health 12, 6725-6744. 
Yu, Ya-qi, Yang, Jin-yan, 2019. Oral bioaccessibility and health risk assessment of vanadium(IV) and vanadium $(\mathrm{V})$ in a vanadium titanomagnetite mining region by a whole digestive system in-vitro method (WDSM). Chemosphere 215, 294-304.

Zorpas, A.A. (2020). Strategy development in the framework of waste management. Sci. Total Environ. 716, 137088. 